\title{
Efficient hydrolytic hydrogen evolution from sodium borohydride catalyzed by polymer immobilized ionic liquid-stabilized platinum nanoparticles
}

\section{Article}

Published Version

Creative Commons: Attribution 4.0 (CC-BY)

Open Access

Doherty, S. ORCID: https://orcid.org/0000-0003-1103-8090, Knight, J. G., Alharbi, H. Y., Paterson, R., Wills, C., Dixon, C., Šiller, L., Chamberlain, T. W., Griffiths, A., Collins, S. M., Wu, K., Simmons, M. D., Bourne, R. A., Lovelock, K. R. J. and Seymour, J. (2022) Efficient hydrolytic hydrogen evolution from sodium borohydride catalyzed by polymer immobilized ionic liquid-stabilized platinum nanoparticles. ChemCatChem, 14 (4). e202101752. ISSN 1867-3899 doi:

https://doi.org/10.1002/cctc.202101752 Available at https://centaur.reading.ac.uk/102316/

It is advisable to refer to the publisher's version if you intend to cite from the work. See Guidance on citing.

To link to this article DOI: http://dx.doi.org/10.1002/cctc.202101752

Publisher: Wiley 
copyright holders. Terms and conditions for use of this material are defined in the End User Agreement.

\section{www.reading.ac.uk/centaur}

\section{CentAUR}

Central Archive at the University of Reading

Reading's research outputs online 


\title{
Efficient Hydrolytic Hydrogen Evolution from Sodium Borohydride Catalyzed by Polymer Immobilized Ionic Liquid-Stabilized Platinum Nanoparticles
}

\author{
Simon Doherty, ${ }^{*[a]}$ Julian G. Knight, ${ }^{*[a]}$ Hussam Y. Alharbi, ${ }^{[a]}$ Reece Paterson, ${ }^{[a]}$ Corinne Wills, ${ }^{[a]}$ \\ Casey Dixon, ${ }^{[a]}$ Lidija Šiller, $^{[b]}$ Thomas W. Chamberlain, ${ }^{*[c]}$ Anthony Griffiths, ${ }^{[c]}$ \\ Sean M. Collins, ${ }^{[c]}$ Kejun Wu, ${ }^{[c]}$ Matthew D. Simmons, ${ }^{[c]}$ Richard A. Bourne, ${ }^{[c]}$ \\ Kevin R. J. Lovelock, ${ }^{[\mathrm{d}]}$ and Jake Seymour ${ }^{[\mathrm{d}]}$
}

\begin{abstract}
Platinum nanoparticles stabilized by imidazolium-based phosphine-decorated Polymer Immobilized lonic Liquids $\left(\mathrm{PPh}_{2-}\right.$ PIIL) catalyze the hydrolytic evolution of hydrogen from sodium borohydride with remarkable efficiency, under mild conditions. The composition of the polymer influences efficiency with the catalyst based on a polyethylene glycol modified imidazolium monomer (PtNP@PPh 2 -PEGPIILS) more active than its $\mathrm{N}$-alkylated counterpart (PtNP@PPh $-\mathrm{N}$-decylPIILS). The maximum initial TOF of $169 \mathrm{moleH}_{2} \cdot \mathrm{molcat}^{-1} \cdot \mathrm{min}^{-1}$ obtained at $30^{\circ} \mathrm{C}$ with a catalyst loading of $0.08 \mathrm{~mol} \%$ is among the highest to be reported for the aqueous phase hydrolysis of sodium borohydride catalyzed by a PtNP-based system. Kinetic studies revealed that the apparent activation energy $\left(E_{a}\right)$ of
\end{abstract}

\section{Introduction}

There is currently an urgent need to reduce our reliance on fossil fuels as this resource is finite and dwindling ${ }^{[1]}$ and, moreover, the resulting emissions have already increased the atmosphere $\mathrm{CO}_{2}$ concentration from the pre-industrial level of $250 \mathrm{ppm}$ to the present level of $420 \mathrm{ppm}$ (as of July 2020), which is having a detrimental impact on our environment (temperature, biodiversity, and oceanic acidification) and health. ${ }^{[2]}$ One potential solution is to harness the sun's energy by using it to produce hydrogen as a clean renewable energy carrier; ${ }^{[3]}$ the resulting $\mathrm{CO}_{2}$-free energy economy would also mitigate climate change and limit further damage to the environment as the only by-product from its use, in, for
$23.9 \mathrm{~kJ} \mathrm{~mol}^{-1}$ for the hydrolysis of $\mathrm{NaBH}_{4}$ catalyzed by PtNP@PPh ${ }_{2}$-PEGPIILS is significantly lower than that of $35.6 \mathrm{~kJ} \mathrm{~mol}^{-1}$ for PtNP@PPh $-\mathrm{N}$-decylPIILS. Primary kinetic isotope effects $k_{\mathrm{H}} / k_{\mathrm{D}}$ of 1.8 and 2.1 obtained with $\mathrm{PtNP} @ \mathrm{PPh}_{2}$ PEGPIILS and PtNP@PPh ${ }_{2}-N$-decyIPIILS, respectively, for the hydrolysis with $\mathrm{D}_{2} \mathrm{O}$ support a mechanism involving rate determining oxidative addition or $\sigma$-bond metathesis of the $\mathrm{O}-\mathrm{H}$ bond. Catalyst stability and reuse studies showed that PtNP@PPh ${ }_{2}$-PEGPILS retained $70 \%$ of its activity across five runs; the gradual drop in conversion appears to be due to poisoning of the catalyst by the accumulated metaborate product as well as the increased viscosity of the reaction mixture. [a] Dr. S. Doherty, Dr. J. G. Knight, H. Y. Alharbi, R. Paterson, Dr. C. Wills, Dr. C. Dixon

Newcastle University Centre for Catalysis (NUCAT)

School of Chemistry, Bedson Building

Newcastle University

Newcastle upon Tyne, NE1 7RU (UK)

E-mail: simon.doherty@ncl.ac.uk

[b] Dr. L. Šiller julian.knight@ncl.ac.uk

School of Engineering, Bedson Building

Newcastle University

Newcastle upon Tyne, NE1 7RU (UK)

[c] Dr. T. W. Chamberlain, A. Griffiths, Dr. S. M. Collins, Dr. K. Wu, instance, a fuel cell, is water. However, as hydrogen is highly flammable with a low volumetric energy density, secure and efficient storage, transport and release are major challenges hindering its implementation as an alternative fuel for clean and sustainable energy applications, particularly in the automotive industry. ${ }^{[4]}$ If this technology is to become commercially viable it will be crucial to address these problems and one potential solution has been to identify or develop new low molecular weight solid-state or liquid hydrogen-storage materials that can release hydrogen efficiently and rapidly under mild conditions. ${ }^{[5]}$ To this end, one of the most promising hydrogen storage materials is $\mathrm{NaBH}_{4}$ as it has a high storage capacity (10.8 wt.\%), is stable, safe, non-toxic, inexpensive and water soluble. ${ }^{[6]}$ Although the high temperatures $\left(>400^{\circ} \mathrm{C}\right)$
Dr. M. D. Simmons, Prof. R. A. Bourne

Institute of Process Research \& Development

School of Chemistry and School of Chemical and Process Engineering University of Leeds

Woodhouse Lane, Leeds LS2 9JT (UK)

E-mail: t.w.chamberlain@leeds.ac.uk

[d] Dr. K. R. J. Lovelock, J. Seymour

School of Chemistry, Food and Pharmacy

University of Reading

Reading, RG6 6AT (UK)

Supporting information for this article is available on the WWW under https://doi.org/10.1002/cctc.202101752

of $\odot 2021$ The Authors. ChemCatChem published by Wiley-VCH GmbH. This is an open access article under the terms of the Creative Commons Attribution License, which permits use, distribution and reproduction in any medium, provided the original work is properly cited. 
required to release hydrogen from $\mathrm{NaBH}_{4}$ limits its practical application, hydrolysis of an aqueous solution has been reported to occur under ambient conditions with a wide range of catalysts [Eq. (1)].

$\mathrm{NaBH}_{4}+4 \mathrm{H}_{2} \mathrm{O} \longrightarrow \mathrm{NaB}(\mathrm{OH})_{4}+4 \mathrm{H}_{2}$

While hydrogen release from $\mathrm{NaBH}_{4}$ has been catalyzed by homogeneous systems, ${ }^{[7]}$ the use of supported metal nanoparticles has recently received increasing attention because their size, surface area, morphology as well as catalyst-support interactions can be tuned to control their efficacy. ${ }^{[8]}$ The high activities achieved with small nanoparticles has been attributed to their high surface area to volume ratio and quantum confinement effects. ${ }^{[9]}$ However, the high surface area of small nanoparticles drives their self-aggregation towards larger species that are less reactive. ${ }^{[10]}$ One potential solution to improve the stability of nanoparticles for catalytic hydrogen generation has been confinement in nanoporous materials including porous carbon structures, ${ }^{[11]}$ zeolites, $_{,}^{[12]}$ mesoporous silicas, ${ }^{[13]}$ porous organic polymers, ${ }^{[14]}$ and metal organic frameworks. ${ }^{[15]}$ More recently, "click" dendrimers have also been introduced as supports for noble metal nanoparticle, late first row transition metal nanoparticle and bimetallic nanoparticlecatalyzed hydrogen evolution from sodium borohydride and ammonia borane and a remarkable synergy between $\mathrm{Pt}$ and Co in Pt/CoNP@dendrimer has been identified. ${ }^{[16]}$ We have recently initiated a program to develop heteroatom donor-decorated PIIL-stabilized nanoparticles on the basis that covalent attachment of the ionic liquid (IL) to the polymer would combine the favorable properties of an IL such as weak electrostatic stabilization of $\mathrm{NPs}^{[17]}$ with the advantages associated with attachment to a solid support including facile product separation, catalyst recovery and recycling. ${ }^{[18]}$ Although heteroatom donors (HADs) were initially incorporated into the polymer to supplement the stabilization of nanoparticle by the ionic liquid, there is now evidence that these donors may well enable the surface electronic structure to be modified to improve catalyst performance and/or the size and morphology of the nanoparticles to be controlled through metal-heteroatom donor interactions. ${ }^{[19]}$ Moreover, the modular construction of these polymers will also enable the hydrophilicity, ionic microenvironment, charge density, functionality, and redox properties to be modified in a systematic manner and, in this regard, heteroatom donor based PIILs may well prove to be versatile supports for improving catalyst efficacy and developing new processes and technology. Our initial foray in this area has shown that phosphine-decorated PEG-modified PIIL stabilized PdNPs are remarkably efficient catalysts for the aqueous phase hydrogenation of $\alpha, \beta$-unsaturated aldehydes, ketones, ester and nitriles, ${ }^{[20 a]}$ the hydrogenation and transfer hydrogenation of nitroarenes in water ${ }^{[20 b]}$ and Suzuki-Miyaura cross-coupling in aqueous media. ${ }^{[20]}$ In addition, gold nanoparticles stabilized by phosphine oxide decorated PIILs catalyze the selective reduction of nitroarenes to afford either $\mathrm{N}$-phenylhydroxylamine, azoxybenzene or aniline as the sole product ${ }^{[20 \mathrm{~d}]}$ while ruthenium nanoparticles stabilized by the same polymer catalyze the hydrogenation of aryl and heteroaryl ketones, furaldehyde, levulinic acid and its esters with remarkable efficacy. ${ }^{[20 e]}$ During a study to explore and optimize the efficiency of PIIL-stabilized platinum nanoparticles as catalysts for the sodium borohydridemediated reduction of quinoline we discovered that competing hydrogen evolution resulting from the hydrolysis of sodium borohydride was responsible for the low conversions of quinoline obtained. To the best of our knowledge there are no reports of the use of ionic liquids or immobilized ionic liquids as supports for the NP-catalyzed hydrolytic generation of hydrogen from hydrogen rich boron derivatives. Herein we compare the efficiency of a PEG-imidazolium and an $\mathrm{N}$-alkyl-imidazoliumbased phosphine-modified polymer immobilized ionic liquid stabilized PtNPs as catalysts for the hydrolytic generation of hydrogen from $\mathrm{NaBH}_{4}$ kinetic studies to explore the mechanism and details of a tandem reaction that used the hydrogen generated from $\mathrm{NaBH}_{4}$ in $\mathrm{D}_{2} \mathrm{O}$ for the hydrogenation of 1,1diphenylethene; eight isotopologues were identified, assigned and quantified by NMR spectroscopy confirming that $H-D$ scrambling was rapid and that $\beta$-hydride elimination-reinsertion also occurred during the hydrogenation.

\section{Results and Discussion}

\section{Synthesis and Characterization of Tetrachloroplatinate Precatalysts and Nanoparticles}

The polymers, tetrachloroplatinate-loaded precursors and the corresponding polymer immobilized ionic liquid-stabilized platinum nanoparticles employed in this project are shown in Figure 1. Polymers $\mathbf{1} \mathbf{a}-\mathbf{b}$ were prepared by AIBN initiated radical polymerization of the constituent imidazolium-based monomer, co-monomer and cross-linker following a previously published procedure. ${ }^{[20]}$ Both polymers were impregnated with the appropriate amount of tetrachloroplatinate to afford metal precursor-loaded PIILs, $\mathbf{2} \mathbf{a}-\mathbf{b}$, with a phosphine to metal stoichiometry of one; the corresponding PIIL-stabilized nanoparticles $\mathbf{3} \mathbf{a}-\mathbf{b}$ were subsequently generated by sodium borohydride-mediated reduction in ethanol. The platinum loadings in precursors $\mathbf{2} \mathbf{a}-\mathbf{b}$ and catalysts $\mathbf{3} \mathbf{a}-\mathbf{b}$ were determined to be $0.43 \mathrm{mmolg}^{-1} / 0.76 \mathrm{mmol} \mathrm{g}^{-1}$, and $0.36 \mathrm{mmol} \mathrm{g}^{-1}$ / $0.77 \mathrm{mmolg}^{-1}$, respectively, using ICP-OES. The ${ }^{13} \mathrm{C}$ CP/MAS NMR spectra of $\mathbf{2} \mathbf{a}-\mathbf{b}$ and $\mathbf{3} \mathbf{a}-\mathbf{b}$ each contain a characteristic

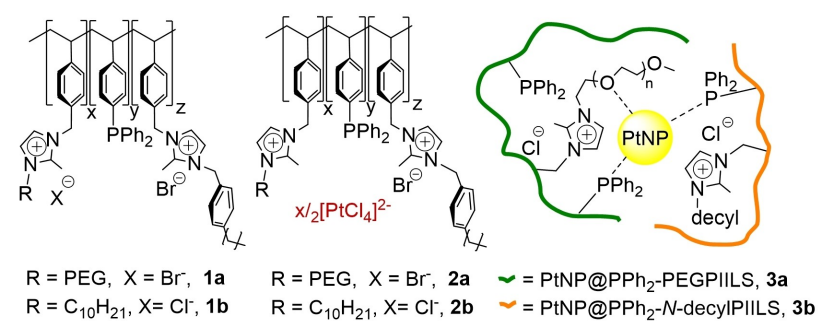

Figure 1. Composition of polymers $\mathbf{1} \mathbf{a}-\mathbf{b}$, tetrachoroplatinate impregnated precursors $\mathbf{2} \mathbf{a}-\mathbf{b}$ and polymer immobilised ionic liquid-stabilized platinum nanoparticles $\mathbf{3} \mathbf{a}$ (green) and $\mathbf{3} \mathbf{b}$ (orange). 
set of signals between $\delta 123$ and $144 \mathrm{ppm}$ associated with the imidazolium ring and the aromatic carbons atoms as well as additional signals at higher field in the range $\delta 12-51 \mathrm{ppm}$, which correspond to the methyl and methylene groups attached to the imidazolium ring and the aliphatic carbon atoms of the polystyrene backbone. An additional intense polymer specific signal at $\delta 70 \mathrm{ppm}$ with a weaker signal at $c a$. $\delta 59 \mathrm{ppm}$ for $2 \mathrm{a}$ and $\mathbf{3} \mathrm{a}$ are associated with the carbon atoms of the PEG chain and terminal OMe, respectively, The solid state ${ }^{31} \mathrm{P}$ NMR spectra of $\mathbf{2} \mathbf{a}$ and $\mathbf{2} \mathbf{b}$ are consistent with the presence of a Pt-P interaction as the chemical shifts of $\delta 23 \mathrm{ppm}$ and $\delta$ $18 \mathrm{ppm}$, respectively, are at much lower field than the corresponding signal for polymers $\mathbf{1} \mathbf{a}-\mathbf{b}$ which appear at $\delta$ -6.7 and $-6.6 \mathrm{ppm}$, respectively (see supporting information for full details). ${ }^{[20]}$ Similarly, the solid state ${ }^{31} \mathrm{P}$ NMR spectra of 3 a and $\mathbf{3} \mathbf{b}$ contain a set of resonances at ca. $\delta 25 \mathrm{ppm}$ and $\delta$ $23 \mathrm{ppm}$, respectively, which suggests that the surface of the platinum nanoparticles are also decorated with phosphine. These complexation shifts are similar to that reported for ultrasmall platinum nanoparticles stabilized on triphenylphosphine-modified silica which appeared at $\delta 28.5 \mathrm{ppm}$ compared with $\delta-5.6 \mathrm{ppm}$ for the high surface area triphenylphosphine polymer. ${ }^{[19 c]}$

Surface characterization of the tetrachloroplatinate-loaded precursors $\mathbf{2}$ a and $\mathbf{2}$ b was undertaken by $\mathrm{X}$-ray photoelectron spectroscopy (XPS). Two Pt $4 \mathrm{f}_{7 / 2}$ and $\mathrm{Pt} 4 \mathrm{f}_{5 / 2}$ doublets were fitted, indicating the presence of two Pt $4 \mathrm{f}$ electronic environments. The binding energies of both $P t 4 f_{7 / 2}$ peaks for $2 \mathrm{a}$, at $72.7 \mathrm{eV}$ and $73.8 \mathrm{eV}$, were indicative of $\mathrm{Pt}^{0}$ and $\mathrm{Pt}^{2+}$ species, respectively, whereas the binding energies of both $P t 4 f_{7 / 2}$ peaks for $\mathbf{2} \mathbf{b}$, at $72.3 \mathrm{eV}$ and $74.8 \mathrm{eV}$, were indicative of $\mathrm{Pt}^{0}$ and $\mathrm{Pt}^{4+}$ species, respectively (see Figure 2 and Figures $\mathrm{S} 25$ and S30 in $\mathrm{SI}$ ). The X-ray photoelectron spectra of $\mathbf{3 a}$ and $\mathbf{3} \mathbf{b}$ (Figure 2) contained a single $P t 4 f_{7 / 2}$ and $P t 4 f_{5 / 2}$ doublet with binding energies of $72.6 \mathrm{eV}$ and $75.9 \mathrm{eV}$ respectively, consistent with the presence of $\mathrm{Pt}^{0} .^{[21]}$

TEM micrographs of $\mathbf{3} \mathbf{a}$ and $\mathbf{3} \mathbf{b}$ revealed that the platinum nanoparticles were near monodisperse with average diameters of $3.0 \pm 0.8 \mathrm{~nm}$ and $2.7 \pm 1.1 \mathrm{~nm}$, respectively. Representative micrographs and associated distribution histograms based on the sizing of $>100$ particles are shown in Figure $3 .{ }^{[20]}$ For comparison, PtNPs stabilized by triphenylphosphine-modified silica are less than $1 \mathrm{~nm}$ in diameter and smaller than those on unmodified silica; spectroscopic studies also confirmed the presence of a strong Pt-P interaction between the $\mathrm{PPh}_{3}$ and PtNPs, ${ }^{[19 c]}$ while the mean diameters of PtNPs embedded in ZIF$8(3.4 \mathrm{~nm})^{[15 \mathrm{~b}]}$ or stabilized by first or second generation click dendrimers $(2.3 \mathrm{~nm})^{[16 c]}$ are similar to those in $\mathbf{3} \mathbf{a}$ and $\mathbf{3} \mathbf{~} \mathbf{b}$.

\section{PtNP-Catalyzed Hydrolysis of Sodium Borohydride}

As the hydrolysis of sodium borohydride occurs under ambient conditions, hydrogen evolution from a solution of sodium borohydride was measured as a function of time at various temperatures ranging from 21 to $40^{\circ} \mathrm{C}$ and all the data obtained during this project was corrected by subtracting the

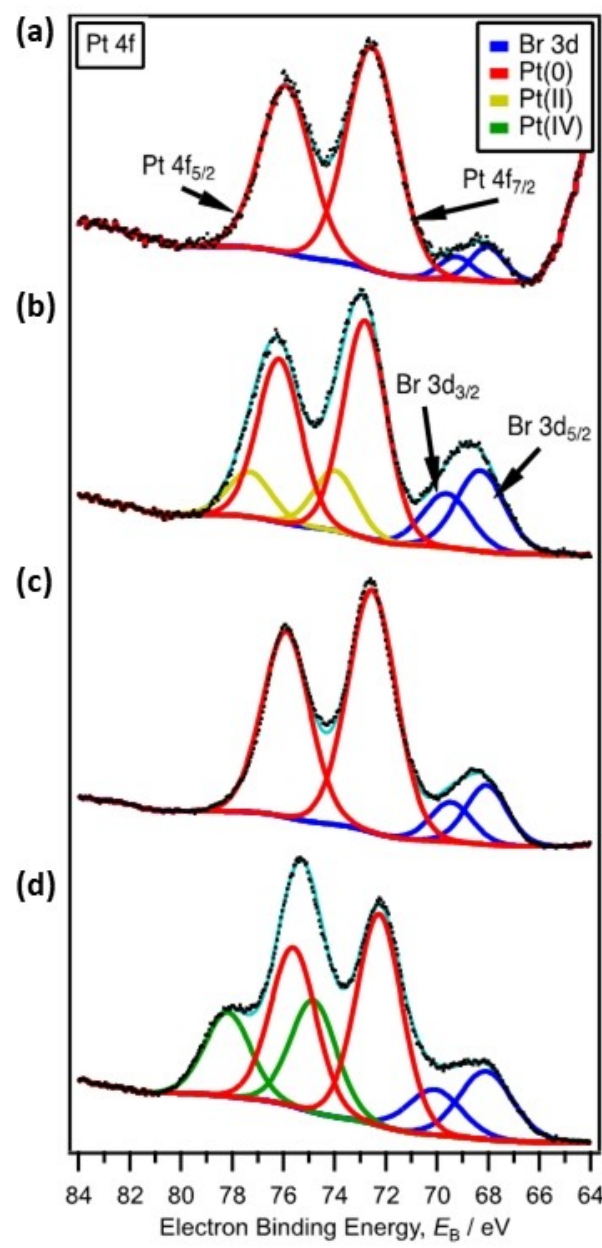

Figure 2. Pt $4 f$ core-level XPS spectra of (a) $\mathbf{3} a$ and (b) $\mathbf{3} b$, referenced to the $\mathrm{Au} 4 \mathrm{f}_{7 / 2}$ peak at $84.0 \mathrm{eV}$.

background hydrogen gas generated in the absence of catalyst under the appropriate conditions. Preliminary catalytic studies were conducted at $30^{\circ} \mathrm{C}$ using $0.32 \mathrm{~mol} \%$ of $3 \mathrm{a}$ and $3 \mathrm{~b}$ for the catalytic hydrolysis of a $0.27 \mathrm{M}$ solution of sodium borohydride, details of which are presented graphically in Figure 4. The progress of the reaction was monitored by using water displacement from a burette system to measure the volume of hydrogen liberated as a function of time. Under these conditions, rapid evolution of hydrogen starts immediately without an induction period, consistent with the metallic state of the platinum. Baseline hydrolysis reactions conducted in the presence of polymers $1 \mathrm{a}$ and $\mathbf{1} \mathbf{b}$ revealed that both supports were inactive as the hydrogen generation did not exceed that of the background reaction. The initial TOF of 81 mole $_{\mathrm{H} 2} \cdot \mathrm{mol}_{\mathrm{cat}}{ }^{-1} \cdot \mathrm{min}^{-1}$ for $3 \mathrm{a}$ is significantly higher than the $29 \mathrm{~mole}_{\mathrm{H} 2} \cdot \mathrm{mol}_{\mathrm{cat}}{ }^{-1} \cdot \mathrm{min}^{-1}$ for $3 \mathbf{b}$, and markedly higher than the hydrogen generation rate of $6.09 \mathrm{~mole}_{\mathrm{H} 2} \cdot \mathrm{mol}_{\mathrm{cat}}{ }^{-1} \cdot \mathrm{min}^{-1}$ in the presence of $1 \mathrm{wt} \% \mathrm{Pt} / \mathrm{C}$ at $40^{\circ} \mathrm{C}$ for a dilute solution of $\mathrm{NaBH}_{4}{ }^{\text {[22a] }}$ and $52 \mathrm{~mole}_{\mathrm{H} 2} \cdot \mathrm{mol}_{\mathrm{cat}}{ }^{-1} \cdot \mathrm{min}^{-1}$ with a commercial sample of $5 \mathrm{wt} \% \mathrm{Pt} / \mathrm{C}^{[22 \mathrm{~b}]}$ The initial TOFs improved to $169 \mathrm{~mole}_{\mathrm{H} 2} \cdot \mathrm{mol}_{\mathrm{cat}}{ }^{-1} \cdot \mathrm{min}^{-1}$ and $78 \mathrm{~mole}_{\mathrm{H} 2} \cdot \mathrm{mol}_{\mathrm{cat}}{ }^{-1} \cdot \mathrm{min}^{-1}$ for $3 \mathrm{a}$ 

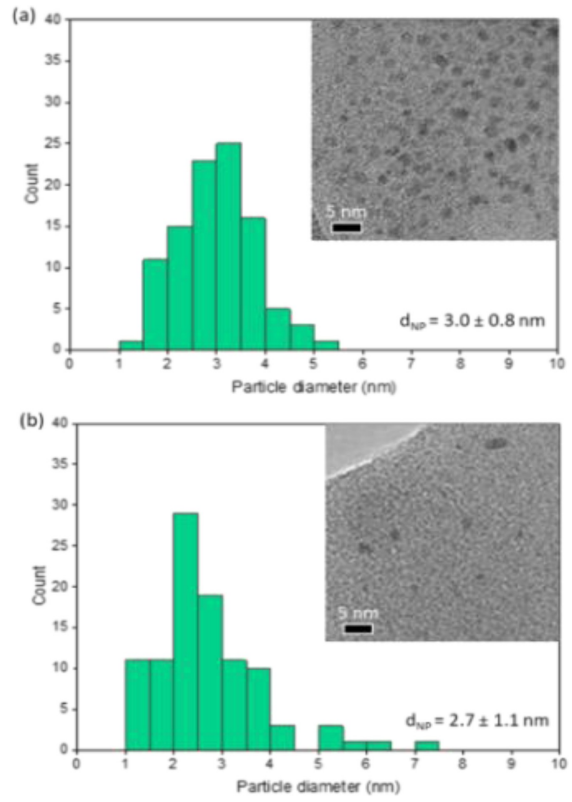

Figure 3. Sizing histograms of PtNPs for (a) $\mathbf{3} a$ and (b) $\mathbf{3} \mathbf{b}$. TEM images of the materials are shown inset for each material

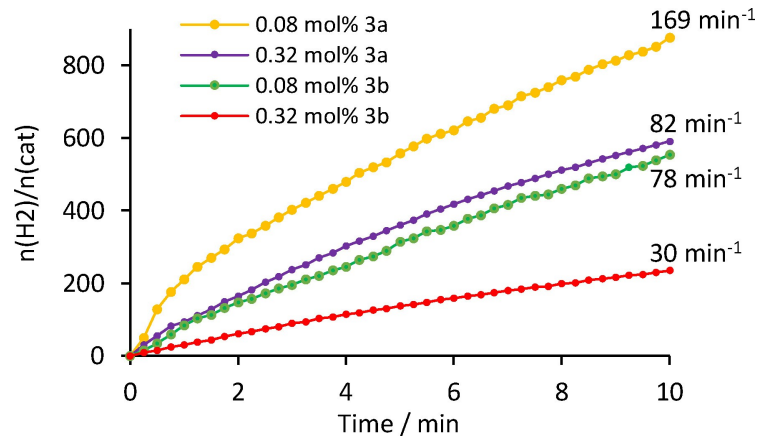

Figure 4. Hydrolytic release of hydrogen from $\mathrm{NaBH}_{4}$ as a function of time at $30^{\circ} \mathrm{C}$ catalyzed by $0.32 \mathrm{~mol} \%$ and $0.08 \mathrm{~mol} \%$ of $3 \mathrm{a}$ and $3 \mathrm{~b}$, respectively, and the corresponding initial TOFs.

and $3 \mathbf{b}$, respectively, when the reaction was conducted in dilute solution $\left(10 \mathrm{~mL}\right.$ of a $0.054 \mathrm{M}$ solution of $\mathrm{NaBH}_{4}$ ) with a reduced catalyst loading of $0.08 \mathrm{~mol} \%$; these values are probably more representative of the intrinsic turnover rates of these catalysts.

While a direct comparison to literature reports of other supported platinum catalysts is complicated and limited in value and credibility because of the disparate experimental conditions and methods, a survey of the recent literature (Table S5 in the ESI) reveals that the initial TOF of

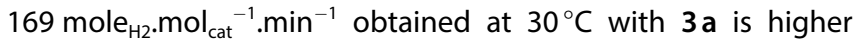
than that of $133 \mathrm{~mole}_{\mathrm{H} 2} \cdot \mathrm{mol}_{\mathrm{cat}}{ }^{-1} \cdot \mathrm{min}^{-1}$ reported for a PtNP@dendrimer, ${ }^{[16 a]} 117 \mathrm{~mole}_{\mathrm{H} 2} \cdot \mathrm{mol}_{\mathrm{cat}}{ }^{-1} \cdot \mathrm{min}^{-1}$ obtained at $80^{\circ} \mathrm{C}$ with monodisperse PtNPs supported on mesoporous silicon nitrides, ${ }^{[23 a, b]}$ and a significant improvement on 8.35 mole $_{\mathrm{H} 2} \cdot \mathrm{mol}_{\mathrm{cat}}{ }^{-1} \cdot \mathrm{min}^{-1}$ for PtNPs supported on multi-walled carbon nanotubes, ${ }^{[23 \mathrm{c}]} 82.6 \mathrm{~mole}_{\mathrm{H} 2} \cdot \mathrm{mol}_{\mathrm{cat}}{ }^{-1} \cdot \mathrm{min}^{-1}$ for graphene- supported PtNPs, ${ }^{[23 \mathrm{~d}]} 69 \mathrm{~mole}_{\mathrm{H} 2} \cdot \mathrm{mol}_{\mathrm{cat}}{ }^{-1} \cdot \mathrm{min}^{-1}$ for $\mathrm{Pt}$ atomic clusters on $\mathrm{CeO}_{2}-\mathrm{Co}_{7} \mathrm{Ni}_{2} \mathrm{O}_{\mathrm{x}}{ }^{[23 \mathrm{e}]} 53 \mathrm{~mole}_{\mathrm{H} 2} \cdot \mathrm{mol}_{\mathrm{cat}}{ }^{-1} \cdot \mathrm{min}^{-1}$ in a flow reactor with a monolithic PtNP/ $/ \mathrm{Al}_{2} \mathrm{O}_{3} /$ cordierite catalyst, ${ }^{[23]} 41-$ $60 \mathrm{~mole}_{\mathrm{H} 2} \cdot \mathrm{mol}_{\mathrm{cat}}{ }^{-1} \cdot \mathrm{min}^{-1}$ with a silicon-aluminum-carbon-nitrogen $(\mathrm{Si} / \mathrm{Al} / \mathrm{C} / \mathrm{N})$ framework impregnated with $\mathrm{PtNPs}^{[23 g]}$

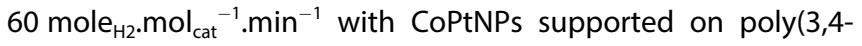
ethylenedioxythiophene)/poly(styrenesulfonate) functionalized multi-walled carbon nanotubes, ${ }^{[23 \mathrm{~h}]} 78 \mathrm{~mole}_{\mathrm{H} 2} \cdot \mathrm{mol}_{\mathrm{cat}}{ }^{-1} \cdot \mathrm{min}^{-1} \mathrm{ob}-$ tained at $80^{\circ} \mathrm{C}$ with PtNPs supported on a TiN/ $\mathrm{Si}_{3} \mathrm{~N}_{4}$ nanocomposite, ${ }_{[}^{23 i]}$ comparable to that of 156 obtained at $70^{\circ} \mathrm{C}$ with fibre-shaped cobalt coated with PtNPs, ${ }^{[23]}$ but lower than that of $330 \mathrm{~mole}_{\mathrm{H} 2} \cdot \mathrm{mol}_{\mathrm{cat}}{ }^{-1} \cdot \mathrm{min}^{-1}$ with micro/mesoporous platinum$\mathrm{SiCN}$ nanocomposites, ${ }^{[23 \mathrm{k}]}$ and $780 \mathrm{~mole}_{\mathrm{H} 2} \cdot \mathrm{mol}_{\mathrm{cat}}{ }^{-1} \cdot \mathrm{min}^{-1}$ $\left(90,000 \mathrm{~mL} \mathrm{~min}^{-1} \mathrm{~g}^{-1}{ }_{\text {cat }}\right)$ for nanoporous platinum; ${ }^{[23]]}$ the latter is currently the most active noble metal catalyst for this reaction.

There have been numerous reports of sodium hydroxide enhancing the efficacy of metal nanoparticle-based catalysts for the hydrolysis of $\mathrm{NaBH}_{4}$ and ammonia borane which has been attributed to coordination of $\mathrm{OH}^{-}$to the surface of the NP enhancing its electron density and thereby facilitating oxidative addition of the $\mathrm{O}-\mathrm{H}$ bond. To this end, significant improvements in the rate of hydrolysis have been achieved with click dendrimer stabilized $\mathrm{Rh}, \mathrm{Ru}, \mathrm{Pd}, \mathrm{Au}$ and Ni nanoparticles, ${ }^{[16 a]} \mathrm{Co}$ and $\mathrm{Ni}$ nanoparticles embedded in the zeolitic imidazolate framework of $\mathrm{ZIF}-8,{ }^{[15 b, e]}$ bimetallic nanoparticle CoPt and $\mathrm{Ni}_{2} \mathrm{Pt}$ systems, ${ }^{[15 c, 16 c]}$ non-noble metal CuCoMo containing nanoparticles, ${ }^{[24]}$ and NiCoP on oxygen-doped porous carbon. ${ }^{[25]}$ However, the presence of $\mathrm{NaOH}$ has been reported to have a negative impact on Pt-based nanoparticles as platinum is highly electron rich and readily promotes oxidative addition of an $\mathrm{O}-\mathrm{H}$ bond in the surface bound activated hydrogen-bonded adduct $\left[\mathrm{BH}_{3} \mathrm{H}^{-}\right]-\mathrm{H}-\mathrm{OH}$. As there is no need to further enhance the electron density of the PtNP surface, the added $\mathrm{OH}^{-}$has been proposed to occupy surface active sites which prevents substrate coordination and activation. ${ }^{16 a-c}$ Interested in exploring the influence of $\mathrm{NaOH}$ concentration on the performance of $3 \mathrm{a}$ as a catalyst for the hydrolysis of $\mathrm{NaBH}_{4}$, the initial TOF was studied as a function of the amount of added sodium hydroxide at $21{ }^{\circ} \mathrm{C}$ by varying the concentration between $0.035 \mathrm{mM}$ and $1.12 \mathrm{mM}$. The data in Figure 5 shows a slight but measurable increase in the initial TOF for PtNP@PPh - -PEGPIILS (3a) with increasing concentration of $\mathrm{NaOH}$ up to an optimum of

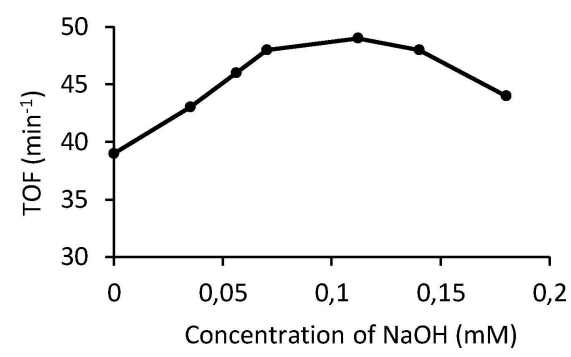

Figure 5. TOFs for the catalytic hydrolysis of $2 \mathrm{~mL}$ of an aqueous solution of $\mathrm{NaBH}_{4}(0.021 \mathrm{~g}, 0.57 \mathrm{mmol})$ at $21^{\circ} \mathrm{C}$ with $0.32 \mathrm{~mol} \% 3 \mathrm{a}$ as a function of the sodium hydroxide concentration. 
49 mole $_{\mathrm{H} 2} \cdot \mathrm{mol}_{\mathrm{cat}^{-1}}{ }^{-1} \mathrm{~min}^{-1}$ in $0.14 \mathrm{mM}$, compared with 39 mole $_{\mathrm{H} 2} \cdot \mathrm{mol}_{\mathrm{cat}}{ }^{-1} \cdot \mathrm{min}^{-1}$ in the absence of $\mathrm{NaOH}$; the TOF then decreased with a further increase in the $\mathrm{NaOH}$ concentration. Rather than exerting a negative effect by coordinating to the surface, as previously suggested, the hydroxide may modify the catalyst-support interactions to render substrate activation more favourable. The dispersity of the catalyst in the reaction mixture was observed not to change as a function of $\mathrm{NaOH}$ (See Figure S51 in the ESI file) so can be ruled out as the reason for the observed change in TOF.

The disparate performance of $\mathbf{3 a}$ and $\mathbf{3 b}$, as measured by the initial TOFs, prompted us to undertake comparative kinetic studies with $\mathbf{3} \mathbf{a}$ and $\mathbf{3} \mathbf{b}$ to investigate the temperature dependence of the rate as well as the influence of catalyst and sodium borohydride concentration on the kinetics of hydrolysis. Hydrolytic reactions were conducted to monitor the initial rate as a function of time at various temperatures ranging from 294 to $313 \mathrm{~K}$. The apparent activation energies $\left(E_{a}\right)$ for the hydrolysis of a $0.27 \mathrm{M}$ solution of $\mathrm{NaBH}_{4}$ catalyzed by $0.32 \mathrm{~mol} \% 3 \mathrm{a}$ and $0.69 \mathrm{~mol} \% 3 \mathrm{~b}$ were determined to be $23.9 \mathrm{~kJ} \mathrm{~mol}^{-1}$ and $35.6 \mathrm{~kJ} \mathrm{~mol}^{-1}$, respectively, from an Arrhenius plot of In $\mathrm{k}$ against $1 / T\left(\operatorname{lnk}=\ln A-E_{a} / R T\right)$; where the initial rates $(k)$ were determined from the linear portion of the graph (Figure $6 a-b)$. These values fall in the region for other noble metal nanoparticle-based systems including $32.1 \mathrm{~kJ} \mathrm{~mol}^{-1}$ for a nanoporous platinum catalyst prepared by chemical etching, ${ }^{[23 i]} 24.9 \mathrm{~kJ} \mathrm{~mol}^{-1}$ for a Pt/ Co@dendrimer-based catalyst, ${ }^{[16 a]} 47.4 \mathrm{~kJ} \mathrm{~mol}^{-1}$ for platinum atomic cluster on cobalt nickel oxide- $\mathrm{CeO}_{2}{ }^{[23 \mathrm{e}]} 46.3 \mathrm{~kJ} \mathrm{~mol}^{-1}$ for PtNPs supported by a polymer-derived silicon carbonitride structure, $^{[23 \mathrm{~h}]} \quad 39.2 \mathrm{~kJ} \mathrm{~mol}^{-1}$ for well-dispersed PtNPs, ${ }^{[26]}$ $36.0 \mathrm{~kJ} \mathrm{~mol}^{-1}$ for carbon-supported platinum, ${ }^{[23 c]} 39.8 \mathrm{~kJ} \mathrm{~mol}^{-1}$ for ruthenium electrodeposited on nickel foam, ${ }^{[27]}$ and $32 \mathrm{~kJ} \mathrm{~mol}^{-1}$ for zeolite confined RuNPs. ${ }^{[12 c]}$ The lower $E_{a}$ determined for $\mathbf{3 a}$ compared with $\mathbf{3 b}$ is consistent with its efficacy which may be due to either a catalyst-support interaction involving the PEG fragment or the hydrophilicity of the PEGylated support facilitating access of the substrate to the active site. To this end, efficient hydrolysis of $\mathrm{NaBH}_{4}$ requires rapid penetration of the substrate into the polymer support as well as access of the borohydride anion to the surface of the platinum nanoparticle and, in this regard, the hydrophilicity of the PEGylated support would increase the dispersibility of the catalyst in water as well as provide a hydrophilic environment at the nanoparticle surface that facilitates interaction of the borohydride, formation of the hydrogen bonded $\left[\mathrm{BH}_{3}-\mathrm{H}-\mathrm{H}-\mathrm{OH}\right]^{-}$ensemble and thereby activation of the water towards oxidative addition.

The activity of $\mathbf{3 a}$ and $\mathbf{3 b}$ for the hydrolytic release of hydrogen from $\mathrm{NaBH}_{4}$ as a function of catalyst concentration was explored across a range of catalyst loadings in $0.27 \mathrm{M}$ $\mathrm{NaBH}_{4}$ at $25^{\circ} \mathrm{C}$ (Figure $7 \mathrm{a}-\mathrm{b}$ ) and logarithmic plots of the hydrogen generation rate versus platinum concentration are straight lines (Figure 7c-d) with slopes of 0.72 and 0.87 , respectively, indicating that the hydrolysis is close to first order

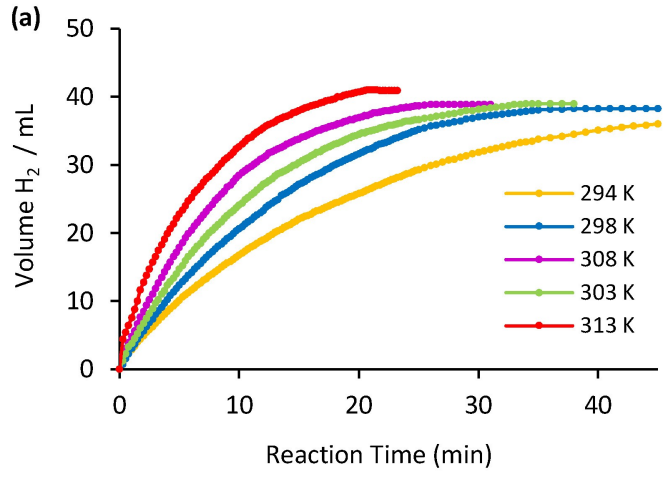

(c)

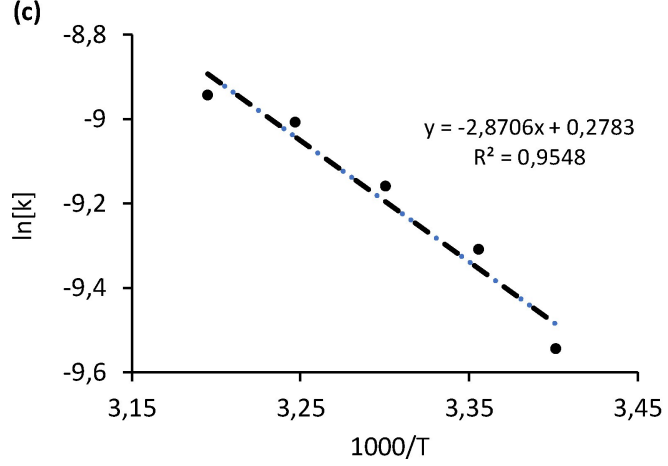

(b)

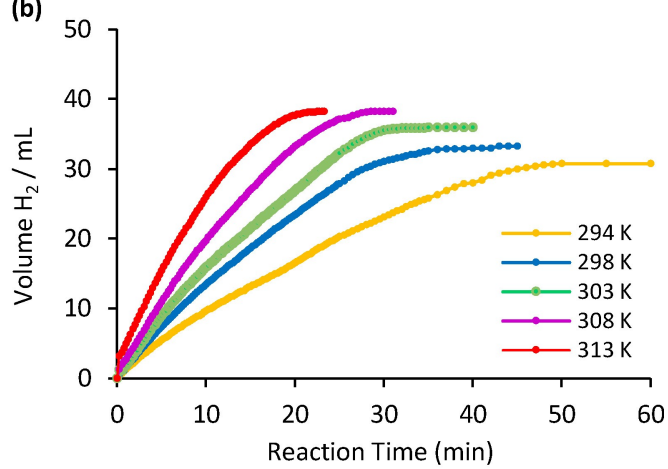

(d)

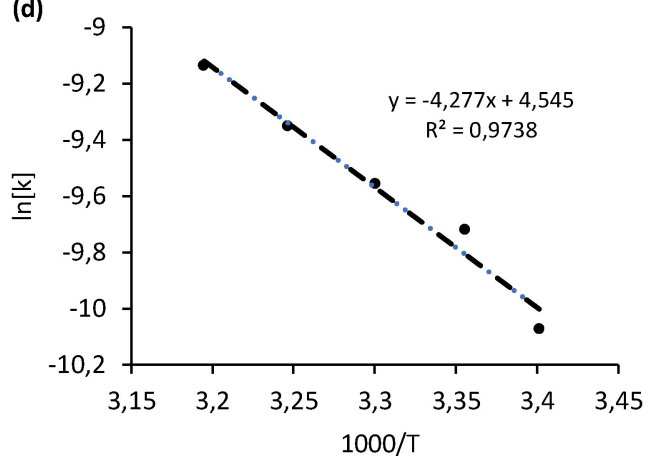

Figure 6. Plots of volume of hydrogen against time for the hydrolysis of $2 \mathrm{~mL}$ of $0.27 \mathrm{M} \mathrm{NaBH}_{4}$ at various temperatures catalyzed by (a) $0.32 \mathrm{~mol} \% 3 \mathrm{a}$ and (b) $0.69 \mathrm{~mol} \% 3 \mathrm{~b}$, respectively; corresponding Arrhenius plots for the hydrolysis of $\mathrm{NaBH}_{4}$ catalyzed by (c) $3 a$ and (d) $3 b$; the initial rates were determined from the slopes of the fitted lines. Volumes measured are an average of three runs. 
(a)

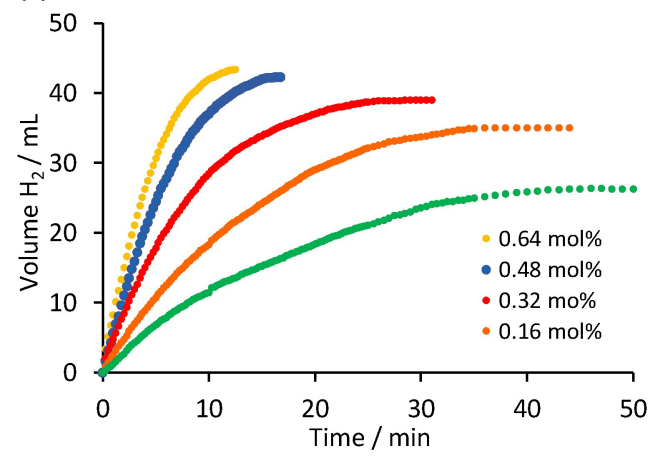

(c)

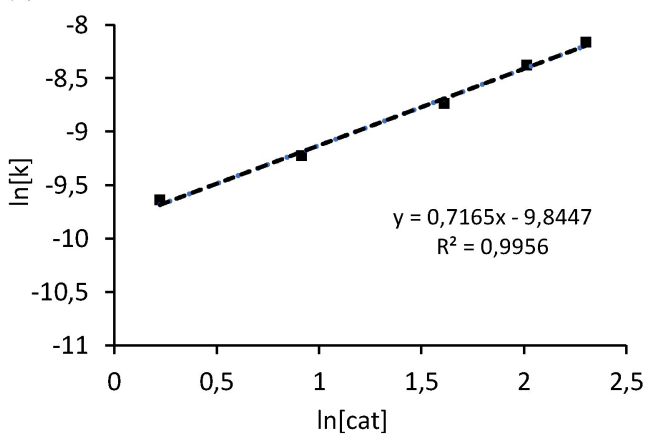

(b)

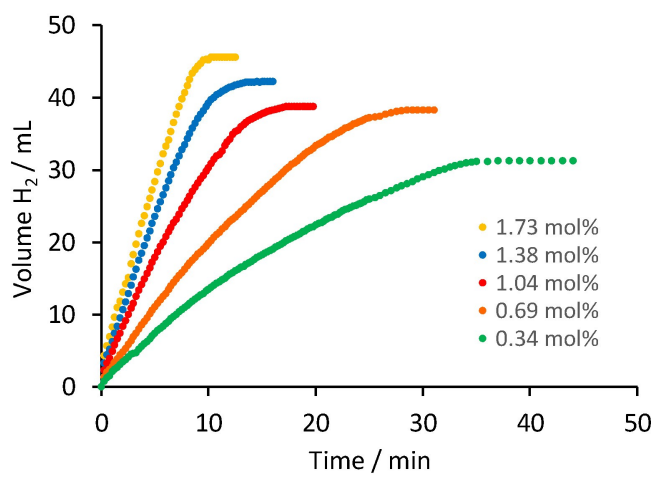

(d)

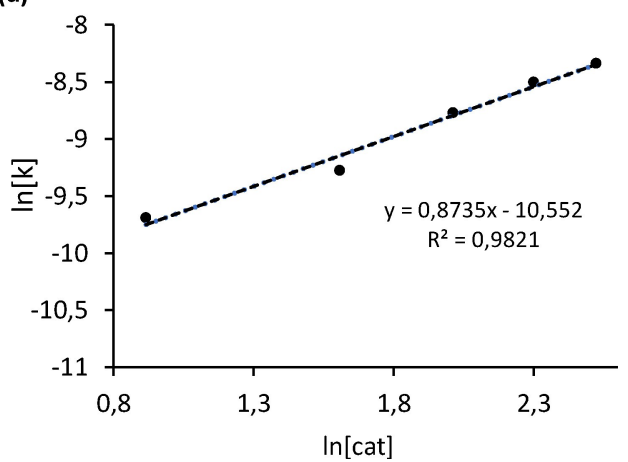

Figure 7. (a) and (b) Plots of volume of hydrogen vs time for the hydrolysis of $2 \mathrm{~mL}$ of $0.27 \mathrm{M} \mathrm{NaBH}_{4}$ at $35^{\circ} \mathrm{C}$ catalyzed by various concentrations of 3 a and $3 \mathbf{b}$, respectively: (c) and (d) plots of hydrogen generation rate vs concentration of catalyst in logarithmic scale for 3 a and $3 \mathbf{b}$, respectively. Volumes measured are an average of three runs.

with respect to catalyst concentration. A survey of the relevant literature revels that this data is consistent with recent reports for the catalytic hydrolysis of hydrogen-rich boron derivatives with platinum-based nanoparticles as well as other noble and non-noble metal nanoparticles. For example, hydrogen evolution from sodium borohydride or ammonia borane catalyzed by Pt/Co@dendrimer (slope=0.85), ${ }^{[16 a, c]}$ zeolite-confined RuNPs (slope $=0.73){ }^{[12 c]} \quad$ PVP-stabilized RuNPs $\quad($ slope $=0.94),{ }^{[28]}$ $\mathrm{Ni}_{2}$ Pt@ZIF-8 (slope $\left.=0.82\right),{ }^{[15 c]}$ NiNP@ZIF-8 (slope 0.98), ${ }^{[15 b]}$ Pt@MWCNT, ${ }^{[23 c]} \mathrm{Ru}, \mathrm{Pt}$ and CoNP@dendrimer (slope $=0.92,0.88$, 0.79 respectively) ${ }^{[16 \mathrm{~b}]}$ and porphyrin-stabilized RuNPs (slope $=$ 1.17). ${ }^{[29]}$

A study of the variation in the rate of hydrolysis of $\mathrm{NaBH}_{4}$ as a function of the substate concentration was also conducted with catalyst $3 \mathrm{a}$ at $30^{\circ} \mathrm{C}$ by varying the initial concentration of $\mathrm{NaBH}_{4}\left(\left[\mathrm{NaBH}_{4}\right]_{0}=0.13,0.26,0.39,0.52,0.65,0.78 \mathrm{mM}\right)$ to obtain kinetic data on a series of reactions with catalyst:substrate ratios between 1:1 and 1:6 (Figure 8a); the corresponding logarithm plot of hydrogen generation rate versus $\mathrm{NaBH}_{4}$ concentration has a slope of 1.08 (Figure $8 \mathrm{c}$ ), which indicates that the hydrolysis is first order with respect to substrate. Similarly, the corresponding kinetic study catalyzed by $\mathbf{3} \mathbf{b}$ was also conducted across the same range of $\mathrm{NaBH}_{4}$ concentrations and the initial rate increased with increasing concentration of $\mathrm{NaBH}_{4}$ (Figure 8b) the slope of 1.16 for the logarithmic plot of the hydrogen generation rate against concentration of $\mathrm{NaBH}_{4}$ means that the hydrolysis catalyzed by $\mathbf{3} \mathbf{b}$ is also first order with respect to substrate and activation of $\mathrm{NaBH}_{4}$ is involved in the rate determining step (Figure $8 \mathrm{~d}$ ).

\section{Kinetic Isotope Effect}

The kinetics of the hydrolytic dehydrogenation of $\mathrm{NaBH}_{4}$ are complicated and depend on the nature of the catalyst, the support as well as the concentration of the substrate and several potential pathways have been proposed. ${ }^{[5 b-c, 1,8 b, 22 b, c]}$ However, studies have consistently shown that sodium borohydride acts as a hydride donor and provides one of the two $\mathrm{H}$ atoms of the released hydrogen while the second $\mathrm{H}$ atom is a proton derived from water ${ }^{[6 \mathrm{~d}]}$ and kinetic isotope effects using $\mathrm{D}_{2} \mathrm{O}$ are consistent with a rate determining step that involves activation of one of the $\mathrm{O}-\mathrm{H}$ bonds of water. ${ }^{[15 e, 16 a, 30]}$ Activation of the absorbed water most likely occurs via oxidative addition which would be facilitated or assisted by a hydrogen-bonding interaction between a water proton and a surface-coordinated borohydride in $\left[\mathrm{H}_{3} \mathrm{~B}-\mathrm{H}-\mathrm{H}-\mathrm{OH}\right]^{-}$; such an interaction would promote the oxidative addition by decreasing the electron density of the $\mathrm{O}-\mathrm{H}$ bond. In the final step, the hydrogen would be liberated from the surface either by reductive elimination between water- and borohydride-derived metal hydrides (Figure 9 a) or a concerted $\sigma$-bond metathesis-like process involving a surface-coordinated borohydride and a water-derived $\mathrm{M}-\mathrm{H}$, perhaps assisted by a surface hydroxide (Figure 9b). In the case 
(a)

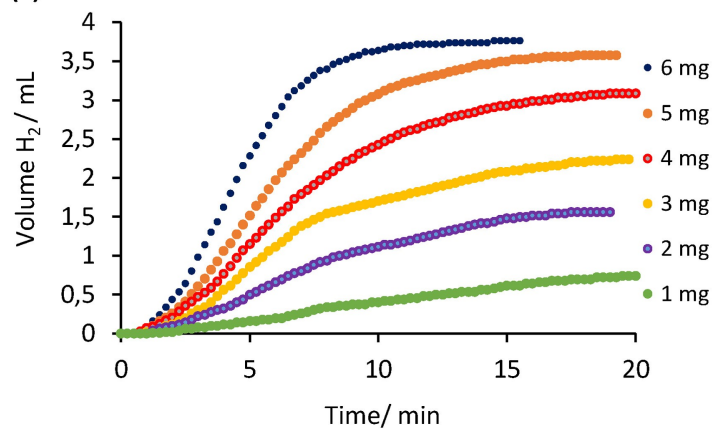

(c)

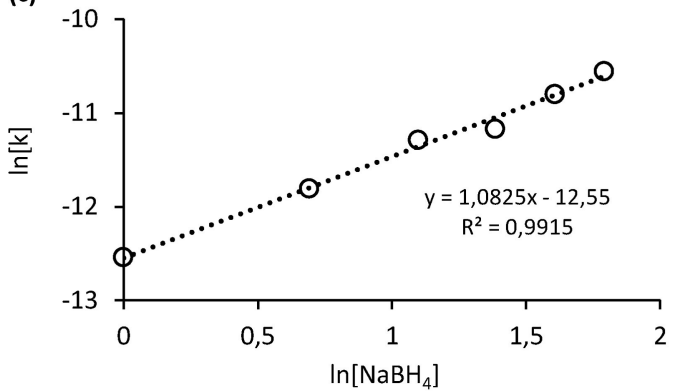

(b)

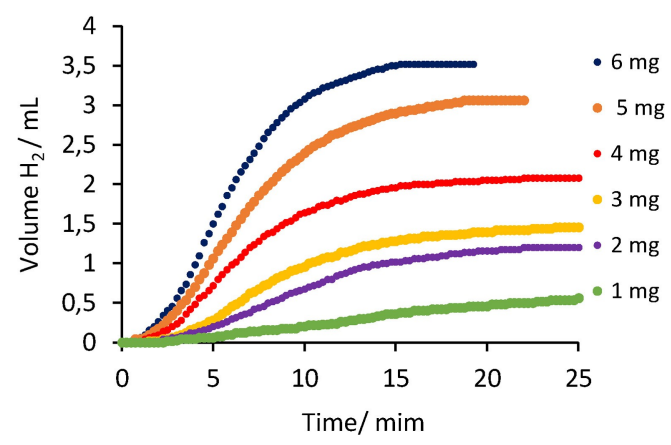

(d)

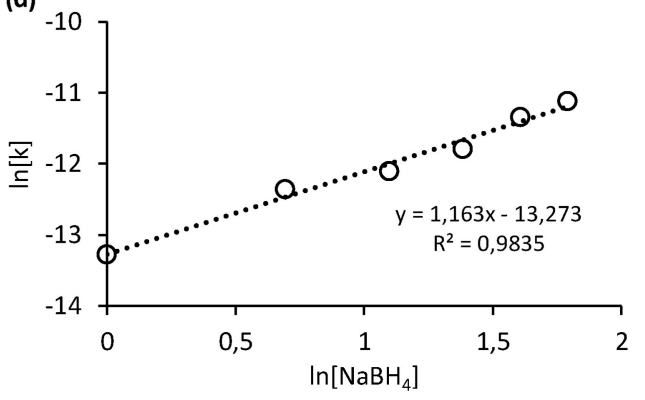

Figure 8. (a) and (b) Plots of volume of hydrogen vs time for the hydrolytic dehydrogenation of $\mathrm{NaBH}_{4}$ catalyzed by $3 \mathrm{a}(0.0725 \mathrm{~g}, 0.026 \mathrm{mmol})$ and $\mathbf{3} \mathrm{b}$ $(0.0340 \mathrm{~g}, 0.026 \mathrm{mmol})$, respectively; reactions were conducted in $200 \mathrm{~mL}$ water and the initial concentration of sodium borohydride varied ([NaBH $]_{0}=0.13$, $0.26,0.39,0.52,0.65,0.78 \mathrm{mM}$ ); (c) and (d) plots of hydrogen generation rate versus concentration of sodium borohydride in logarithmic scale for (c) $3 \mathrm{a}$ and (d) $3 \mathrm{~b}$, respectively. Volumes measured are an average of three runs.

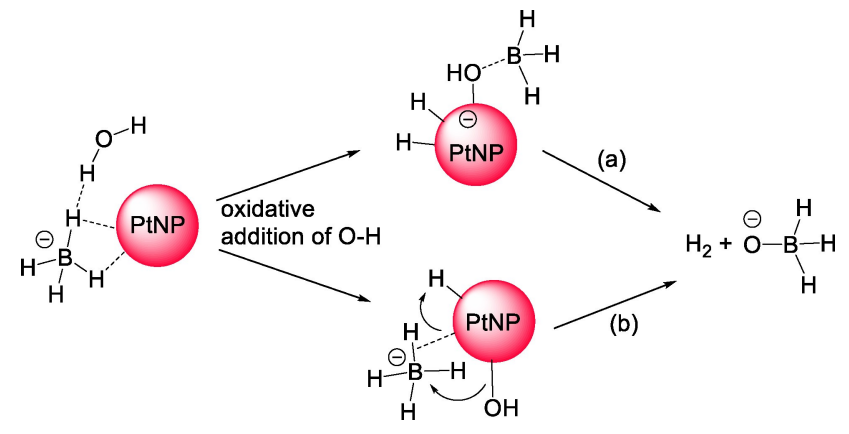

Figure 9. Proposed pathways for PtNP-catalyzed hydrolytic hydrogen evolution from $\mathrm{NaBH}_{4}-$ via oxidative addition of an $\mathrm{O}-\mathrm{H}$ in water involving the hydrogen-bonded surface-coordinated ensemble $\left[\mathrm{H}_{3} \mathrm{~B}-\mathrm{H}-\mathrm{H}-\mathrm{OH}\right]$ followed by either (a) reductive elimination or (b) a $\sigma$-bond metathesis-type process.

of the borohydride-derived metal hydride, transfer of the hydrogen onto the nanoparticle could occur either via oxidative addition of one of the $\mathrm{B}-\mathrm{H}$ bonds or hydride transfer with the negative charge delocalized on the surface; the latter is most likely as borohydrides are powerful transfer reagents. ${ }^{[31]}$ However, we cannot exclude the possibility that activation of the $\mathrm{O}-\mathrm{H}$ bond in water may involve a hydrogen-bonding interaction with a surface-coordinated hydride, i.e. $\mathrm{NP}-\mathrm{H}-\mathrm{H}-\mathrm{OH}$, generated via facile hydride transfer from $\mathrm{NaBH}_{4}$ to the PtNP, rather than involving a surface-coordinated borohydride, as described above.
To this end, the role of $\mathrm{H}_{2} \mathrm{O}$ in the hydrolysis of $\mathrm{NaBH}_{4}$ catalyzed by $\mathbf{3} \mathbf{a}$ and $\mathbf{3} \mathbf{b}$ was explored by conducting reactions at $35^{\circ} \mathrm{C}$ in $\mathrm{D}_{2} \mathrm{O}$ to determine the kinetic isotope effect (KIE). A comparison of the efficacy of $\mathbf{3} \mathbf{a}$ and $\mathbf{3} \mathbf{b}$ as catalysts for the hydrolysis of $\mathrm{NaBH}_{4}$ conducted in $\mathrm{H}_{2} \mathrm{O}$ and $\mathrm{D}_{2} \mathrm{O}$ shows that the reaction is significantly faster in $\mathrm{H}_{2} \mathrm{O}$ than in $\mathrm{D}_{2} \mathrm{O}$ with primary $\mathrm{KIES}\left(k_{H} / k_{D}\right)$ of 1.9 and 2.1 , respectively (Figure 10a-b). As described above, these values are consistent with a rate determining step that involves cleavage of one of the $\mathrm{O}-\mathrm{H}$ bonds of water; these values are consistent with a solvent isotope effect of 1.8 obtained by Guella in a detailed kinetic study on the hydrolysis of $\mathrm{NaBH}_{4}$ using $5 \mathrm{wt} \% \mathrm{Pt} / \mathrm{C}_{1}^{[22 \mathrm{bb}}$ as well as more recent reports with noble and non-noble metal nanoparticle-based systems including NiNP@ZIF-8 $\left(k_{H} / k_{D}=\right.$ $2.49){ }_{1}^{[15 b]}$ dendrimer-stabilized $\mathrm{Rh}$ and Pd nanoparticles $\left(k_{H} / k_{D}=\right.$ 2.3 and 2.8, respectively) ${ }^{[16 b]}$ and PtCo@dendrimer $\left(k_{H} / k_{D}=\right.$ 2.4). ${ }^{[16 c]}$ The corresponding comparison of the efficacy of $3 a$ and 3 b as catalyst for the hydrolysis of $\mathrm{NaBH}_{4}$ and $\mathrm{NaBD}_{4}$ in $\mathrm{H}_{2} \mathrm{O}$ showed only a slight difference in the initial rate of hydrogen evolution with primary KIEs of 1.3 and 1.2 , for $\mathbf{3} \mathbf{a}$ and $\mathbf{3} \mathbf{b}$, respectively, suggesting that $\mathrm{B}-\mathrm{H}(\mathrm{D})$ bond cleavage does not occur in the rate determining step. The absence of a large KIE for hydrolysis of amine-borane and $\mathrm{NaBH}_{4}$ deuterated at the boron has previously been reported for NiNP@ZIF-8 ${ }^{[15 b]}$ and Pt/ $\mathrm{C}_{1}^{[22 \mathrm{~b}]}$ respectively. While the above data is consistent with a mechanism involving rate determining oxidative addition of an $\mathrm{O}-\mathrm{H}$ bond, we cannot unequivocally distinguish between pathways involving a surface coordinated $\mathrm{BH}_{4}$ and a borohy- 
(a)

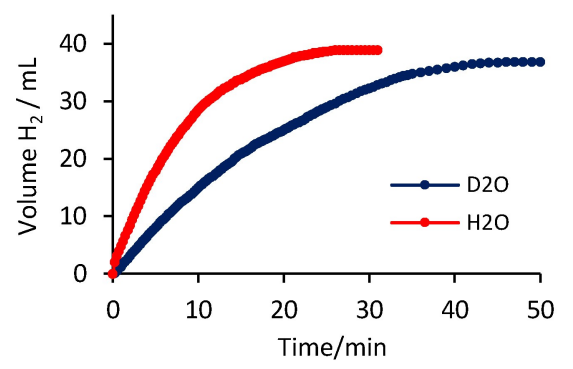

(b)

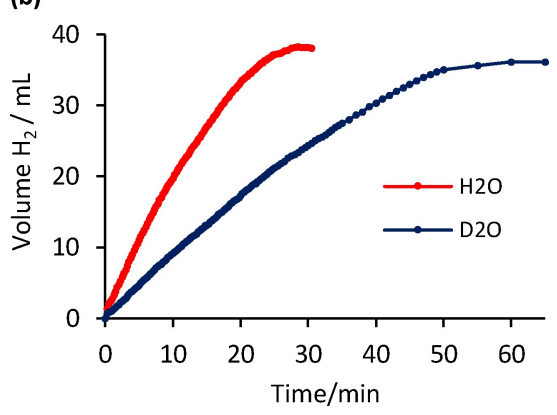

Figure 10. Hydrogen release from a $0.27 \mathrm{M}$ solution of $\mathrm{NaBH}_{4}$ in $\mathrm{H}_{2} \mathrm{O}$ and $\mathrm{D}_{2} \mathrm{O}$ catalyzed by (a) $0.32 \mathrm{~mol} \% 3 \mathrm{a}$ and (b) $0.69 \mathrm{~mol} \% \mathbf{3} \mathbf{b}$ conducted at $35^{\circ} \mathrm{C}$. Volumes measured are an average of three runs.

dride-derived $\mathrm{Pt}-\mathrm{H}$. While both processes may involve a surface-coordinated hydrogen bonded ensemble of the type $\left[\mathrm{H}_{3} \mathrm{BH}^{-}\right]-\mathrm{H}-\mathrm{OH}$ the oxygen atoms of PEG and the ionic liquid environment will influence the hydrophilicity at the surface and thereby assist the $\mathrm{H}$-transfer and/or $\mathrm{O}-\mathrm{H}$ cleavage steps.

A tandem reaction in which the hydrogen generated from the hydrolysis of $\mathrm{NaBH}_{4}$ in $\mathrm{D}_{2} \mathrm{O}$ catalyzed by $0.32 \mathrm{~mol} \% 3 \mathrm{a}$ at $30^{\circ} \mathrm{C}$ was used for the hydrogenation of 1,1-diphenylethene to study the product distribution and thereby further investigate the mechanism. The hydrogen was generated in a sealed reaction flask using $0.32 \mathrm{~mol} \% 3 \mathrm{a}$ at $30^{\circ} \mathrm{C}$; after $60 \mathrm{~min}$ the connector was opened to a second reaction flask containing a solution of 1,1-diphenylethene in $\mathrm{d}_{4}$-methanol with $0.5 \mathrm{~mol} \%$ $\mathrm{Pd} / \mathrm{C}$. The hydrogenation mixture was stirred at $30^{\circ} \mathrm{C}$ for $18 \mathrm{~h}$, after which time ${ }^{1} \mathrm{H}$ NMR spectroscopy confirmed that the reaction had reached $100 \%$ conversion. Analysis of the reaction mixture by a combination of ${ }^{1} \mathrm{H},{ }^{2} \mathrm{H}$, and ${ }^{13} \mathrm{C}$ NMR spectroscopy as well as gas chromatography-mass spectrometry revealed that the hydrogenation generated a mixture of all 8 isotopologues of 1,1-diphenylethane, as shown in Scheme 1.

The assignment is most clear in the methine region of the ${ }^{13} \mathrm{C}\left\{{ }^{1} \mathrm{H}\right\}$ NMR spectrum of the reaction mixture (ca. $\left.\delta 44.5 \mathrm{ppm}\right)$ which contains four singlets at $\delta 44.88, \delta 44.81, \delta 44.74, \delta$ $44.66 \mathrm{ppm}$ associated with I, II, III and IV, respectively. These species were assigned based on the chemical shifts that would be predicted for a two bond ${ }^{13} \mathrm{C}-\mathrm{D}$ isotope shift of $c a$. $0.07 \mathrm{ppm}$. Four $1: 1: 1$ triplets at $\delta 44.46, \delta 44.39, \delta 44.31$ and $\delta$ $44.24 \mathrm{ppm}$ with a $J_{\mathrm{CD}}$ coupling constant of $19.5 \mathrm{~Hz}$ correspond to the remaining isotopologues V, VI, VII, VIII, each with one deuterium on the methine carbon atom and either zero, one, two or three D atoms attached to the methyl group; the stacked spectra in Figure 11 show the simulated spectrum for each isotopologue along with the summed simulated spectrum and the experimental spectrum of the mixture. The simulation confirms the assignment and relative proportion of each of the isotopologues (see Table S3 in the ESI for full details); the coupling constants, line widths, isotope shifts, and signal intensities are entirely consistent with the assignment, moreover, the resonances in the methyl region (ca. $\delta 21 \mathrm{ppm}$ ) have also been assigned and simulated which confirms the distribution of isotopologues and their relative proportions. If the hydrogen generated from the hydrolysis results solely from a borohydride-derived hydride and a $\mathrm{D}_{2} \mathrm{O}$-derived proton the total deuterium count across isotopologues II-VIII would be one. However, the total deuterium count of 2.51 across these species, as determined from the relative proportions, may result from $H / D$ exchange either at the nanoparticle surface to generate a mixture of $D_{2}$ and $H D$ after $O-D$ bond cleavage and/ or with the $d_{4}$-methanol on the surface of the $P d / C$ during the hydrogenation step. This $H / D$ exchange was further explored by conducting the hydrogenation in $\mathrm{d}_{4}$-methanol using hydrogen generated from $\mathrm{NaBH}_{4}$ and $\mathrm{H}_{2} \mathrm{O}$; analysis of the isotopologue distribution gave a total deuterium incorporation of 1.19 , which confirmed that exchange on the surface of the $\mathrm{Pd} / \mathrm{C}$ is rapid, full details are provided in the supporting information. Exchange at the nanoparticle surface was investigated by conducting the $\mathrm{Pd} / \mathrm{C}$ catalyzed hydrogenation in toluene using ' $H D$ ' generated from the hydrolysis of $\mathrm{NaBH}_{4}$ with $\mathrm{D}_{2} \mathrm{O}$ in the presence of catalyst $3 \mathrm{a}$; the total deuterium incorporation of
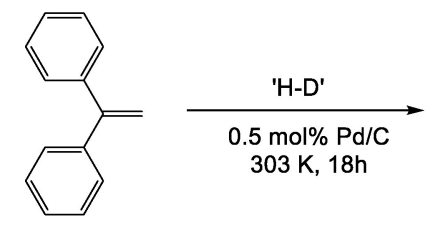
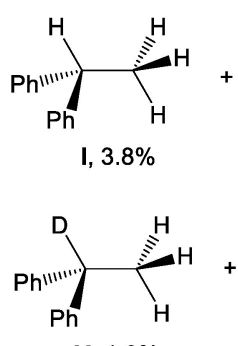

V, $1.0 \%$

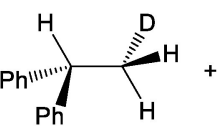

II, $11.0 \%$

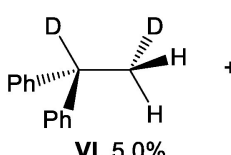

VI, $5.0 \%$

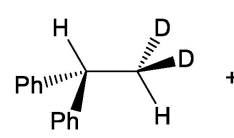

III, $24.4 \%$

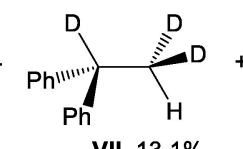

VII, $13.1 \%$

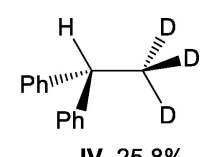

IV, $25.8 \%$

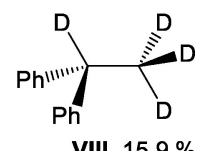

VIII, 15.9. \%

Scheme 1. Hydrogenation of 1,1-diphenylethene in $\mathrm{d}_{4}$-methanol with $\mathrm{HD}$ generated from hydrolysis of $\mathrm{NaBH}_{4}$ in $\mathrm{D}_{2} \mathrm{O}$ catalyzed by 0.32 mol\% 3 a showing the distribution of isotopologues identified and quantified by ${ }^{13} \mathrm{C}$ NMR spectroscopy. 


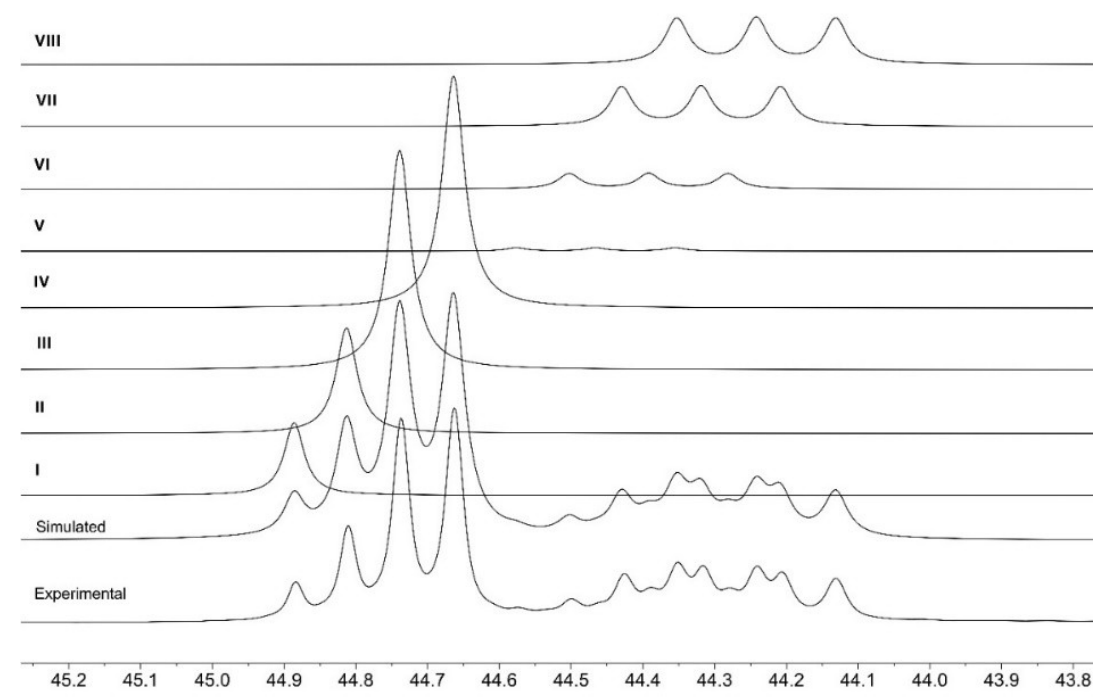

Figure 11. Stacked plot showing the individual simulated spectra, the summed simulated spectrum and the experimental ${ }^{13} \mathrm{C}\left\{{ }^{1} \mathrm{H}\right\} \mathrm{NMR}$ spectrum, in the methine region, of the eight possible hydrogenation products of 1,1-diphenylethene in $\mathrm{d}_{4}-\mathrm{MeOH}$ using hydrogen generated from the hydrolysis of $\mathrm{NaBH}_{4}$ in $\mathrm{D}_{2} \mathrm{O}$ catalyzed by $0.32 \mathrm{~mol} \% 3 \mathrm{a}$.

0.94 was close to the expected value of one if $H / D$ exchange was slow under these conditions. In addition, the generation of significant amounts of isotopologues containing $-\mathrm{CD}_{2} \mathrm{H}$ and $-\mathrm{CD}_{3}$ (III, IV, VII and VIII) is quite remarkable and consistent with facile scrambling via $\beta$-hydride elimination from a surface $\mathrm{M}-\mathrm{CPh}_{2} \mathrm{CH}_{2} \mathrm{D}$ species to generate $\mathrm{Ph}_{2} \mathrm{C}=\mathrm{CHD}$, reinsertion into a $\mathrm{M}-\mathrm{D}$ to afford $\mathrm{M}-\mathrm{CPh}_{2} \mathrm{CHD}_{2}$ followed by reductive elimination; this is far more likely than the alternative pathway involving $\sigma$ bond metathesis between an $\mathrm{M}-\mathrm{D}$ and a $\mathrm{C}-\mathrm{H}$ bond of the methyl fragment in $\mathrm{CPh}_{2} \mathrm{HCH}_{2} \mathrm{D}$. A higher than stoichiometric deuteration of phenylethylene with tetrahydroxydiboron $/ \mathrm{D}_{2} \mathrm{O}$ derived deuterium has recently been described and attributed to the equilibrium of olefin insertion/extrusion involving metalhydride/deuteride species. ${ }^{[32]}$ Scrambling was also shown to be facile when the hydrogenation was conducted in toluene using $D_{2}$ generated from $\mathrm{NaBD}_{4}$ and $\mathrm{D}_{2} \mathrm{O}$; the total deuterium incorporation of 1.65 is close to the expected value of two, details of which are provided in the supporting information.

\section{Catalyst Recycle Studies}

The stability and lifetime of $3 \mathbf{a}$ was investigated for the hydrolysis of sodium borohydride to assess the longevity of the catalyst and the potential for integration into a continuous flow platform, as demonstrated previously for the transfer hydrogenation of nitrobenzene using PdNP@PPh ${ }_{2}$ PEGPIILS as catalyst. ${ }^{[20 b]}$ As the practical problems associated with recovering the small amount of catalyst $(5.0 \mathrm{mg}, 0.32 \mathrm{~mol} \%)$ by filtration would prevent isolation of the catalyst in a conventional recycle, a reuse experiment was conducted by monitoring the amount of gas generated until the reaction was complete. The aqueous mixture was then recharged with an additional portion of sodium borohydride and the sequence repeated to monitor the catalyst performance as a function of reaction time and recycle number. The conversion-time profile in Figure 12a shows that high conversions were obtained across five reuses although a slight increase in reaction time for each run was required to achieve comparable conversions in successive cycles (Table 1). as the conversion achieved after $8 \mathrm{~min}$ dropped from $85 \%$ to $61 \%$ in the $5^{\text {th }}$ run Figure $12 \mathrm{~b}$ shows the loss in

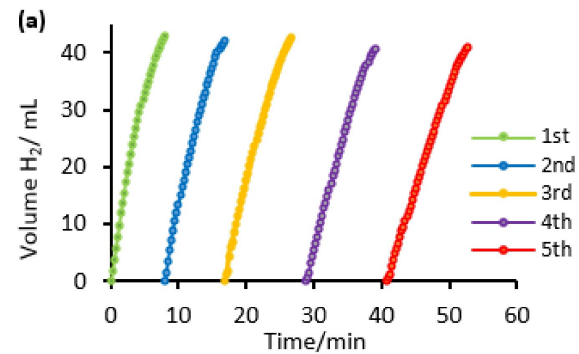

(b)

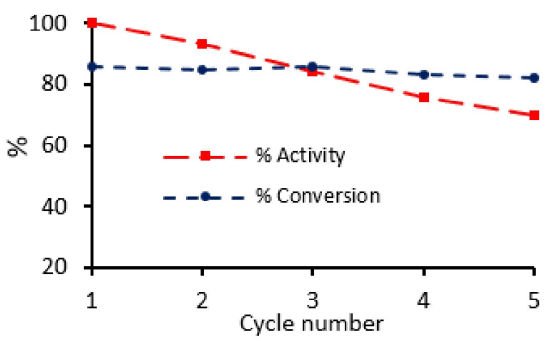

Figure 12. (a) Plots of volume of hydrogen versus time for the hydrolysis of $\mathrm{NaBH}_{4}$ catalyzed by $2 \mathrm{~mol} \% 3 \mathrm{a}$ at $30^{\circ} \mathrm{C}$ during the reusability study across five runs. (b) conversion reached in each run and percentage of initial activity remaining after successive reuses. Volumes measured are an average of three runs. 
Table 1. Conversion as a function of time for the reuse of $3 \mathrm{a}$ as a catalyst for the hydrolysis of $\mathrm{NaBH}_{4}$.

\begin{tabular}{|lll|}
\hline Run & Conversion (\%) & Time (min) \\
\hline $\mathbf{1}$ & 86 & 8 \\
$\mathbf{2}$ & 85 & 8.75 \\
$\mathbf{3}$ & 86 & 10 \\
$\mathbf{4}$ & 83 & 10.25 \\
$\mathbf{5}$ & 82 & 12 \\
\hline
\end{tabular}

catalyst activity in successive reuses, as defined by the percentage decrease in the initial rate based on the slope of the linear portion of the plots in Figure 12a. The profile in Figure $12 \mathrm{~b}$ shows that 3 a retains $c a .70 \%$ of its activity across five runs; this is comparable to recycle studies reported with dendrimer-stabilized PtCo, Rh and Pt nanoparticles, ${ }^{[16 a, b, c]}$ RuNPs embedded in amine-functionalized MIL-53(Al), ${ }^{[15 f]}$ NiNPs dispersed in the zeolitic imidazolate framework of ZIF- $8{ }^{[15 b]}$ RuNP stabilized by polyvinylpyrrolidone, ${ }^{[28]}$ highly dispersed PtNPs generated using $\beta$-cyclodextrin, ${ }^{[26]}$ and zeolite-confined RuNPs, $^{[12 c]}$ each of which retained between $61 \%$ and $75 \%$ activity up to the fifth cycle.

Analysis of the aqueous phase collected after the $5^{\text {th }}$ run revealed that the platinum content was too low to be detected by ICP-OES $\left(<0.1 \mathrm{mgL}^{-1}\right)$ confirming that the reduction in activity was unlikely to be due to leaching of the platinum to generate a less active homogeneous species. EDX analysis of the catalyst after 5 recycles revealed a significant amount of boron fouling on the catalyst, which is proposed to be the reason for the reduction in activity (see ESI for full details). The heterogeneous nature of the active species was explored by conducting a hot filtration test in which a hydrolysis catalyzed by $0.32 \mathrm{~mol} \% 3 \mathrm{a}$ was allowed to reach completion after which the reaction mixture was filtered through a syringe filter $(0.45 \mu \mathrm{m})$ and an additional portion of $\mathrm{NaBH}_{4}$ added to the filtrate. The gas evolution corresponded to the background hydrolysis which confirmed that the active platinum species had been removed. In a complimentary hot filtration test, a hydrolytic reaction mixture was filtered to remove $\mathbf{3} \mathbf{a}$ after it had reached ca. $50 \%$ conversion $(t=8 \mathrm{~min})$; the hydrogen subsequently liberated from the filtrate was quantified and corresponded to uncatalyzed background hydrolysis (Figure 13), which further indicates that the active catalyst is heterogeneous. However, it is important to note that the ICP analysis and the hot filtration test cannot unambiguously distinguish between heterogeneous catalysis at defect sites on the surface of the nanoparticle and a homogeneous process involving leaching and rapid re-deposition.

TEM analysis of the catalyst remaining after the fifth run revealed that the platinum nanoparticles remained unchanged and essentially monodisperse with a mean diameter of $2.6 \pm$ $0.7 \mathrm{~nm}$ compared with $3.0 \pm 0.8 \mathrm{~nm}$ for freshly prepared catalyst (Figure 14).

Thus, agglomeration is not responsible for the drop in conversion with increasing use, however, there have been numerous reports that the sodium metaborate hydrolysis product can deactivate the catalyst by adsorption on the

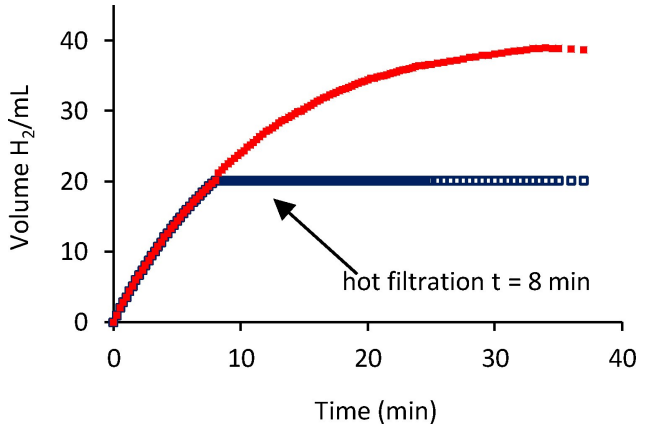

Figure 13. Hot filtration test for the hydrolysis of $\mathrm{NaBH}_{4}$ using $0.32 \mathrm{~mol} \% 3 \mathrm{a}$ showing that turnover has been completely quenched after filtration at $\mathrm{t}=8 \mathrm{~min}$. Red line - reaction in the presence of catalyst; blue line reaction catalyzed by $3 \mathrm{a}$ and filtered to remove catalysts after $8 \mathrm{~min}$.

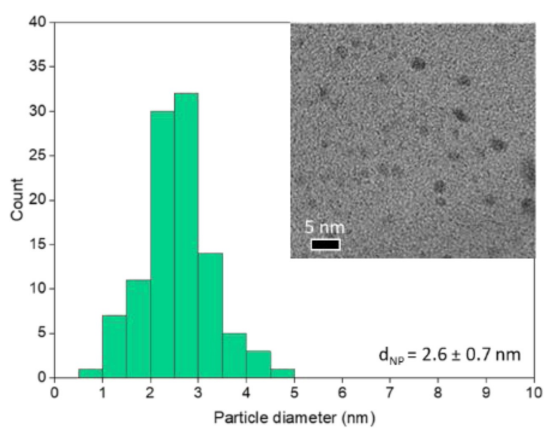

Figure 14. Sizing histogram of PtNPs for 3 a after 5 experimental cycles. A TEM image of the material is shown in the inset.

surface. ${ }^{[13 b, 15 f, 16 c, 33]}$ To this end, a series of parallel reactions were run by pre-stirring an aqueous suspension of catalyst with one equivalent of sodium metaborate prior to addition of sodium borohydride and the activity monitored as a function of prestirring time. A comparison of the catalyst performance in the absence of $\mathrm{NaBO}_{2}$ against the same reaction with added $\mathrm{NaBO}_{2}$ as a function of the pre-stirring time clearly shows that the metaborate poisons or passivates the catalyst (Figure 15a). The corresponding data in Figure 15b shows that this poisoning is instantaneous as there is a dramatic reduction in the conversions obtained after $8 \mathrm{~min}$ from $86 \%$ in the absence of $\mathrm{NaBO}_{2}$ to $63 \%$ upon direct addition of $\mathrm{NaBO}_{2}$ with no prestirring (time $0 \mathrm{~min}$ ). Conversions continued to drop with increasing pre-stirring time to $39 \%$ for $60 \mathrm{~min}$ and ultimately to $32 \%$ after the pre-stirring was increased to $18 \mathrm{~h}$; this stirring time-conversion profile presumably reflects the kinetics of adsorption of the metaborate on the surface of the nanoparticles. Finally, a baseline experiment in which an aqueous solution of the catalyst was stirred for $18 \mathrm{~h}$ prior to addition of $\mathrm{NaBH}_{4}$ gave the same initial TOF and conversion profile as that obtained when the $\mathrm{NaBH}_{4}$ was added to fresh catalyst, which indicates that the catalyst was stable and maintained its activity and that the drop in conversion after $18 \mathrm{~h}$ of pre-stirring with sodium metaborate was due entirely to adsorption of the hydrolysis product on the support and/or surface of the 
(a)



(b)

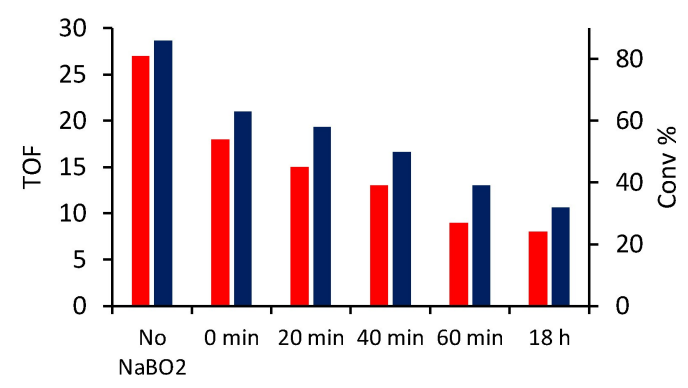

Figure 15. (a) Plot of volume of $\mathrm{H}_{2}$ vs time for the hydrolysis of $\mathrm{NaBH}_{4}$ catalyzed by 2 mol\% 3 a as a function of pre-stirring time with added $\mathrm{NaBO}_{2}$ (b) corresponding conversions and TOFs as a function of $\mathrm{NaBO}_{2}$ pre-stirring time.

nanoparticle. Thus, the decrease in the activity of $\mathbf{3 a}$ is attributed to the deactivation effect of the metaborate product and a slight increase in the size of the PtNPs, although we cannot exclude an increase in the viscosity of the reaction mixture limiting diffusion of the substrate. ${ }^{[15 f]}$

\section{Conclusions}

Polymer immobilized ionic liquid stabilized PtNPs catalyze the hydrolytic evolution of hydrogen from sodium borohydride with remarkable efficiency and catalyst stabilized by PEGmodified imidazolium-based polymer (PtNP@PPh ${ }_{2}$-PEGPIILS) is markedly more active than its $N$-decyl counterpart $\left(\mathrm{PtNP} @ \mathrm{PPh}_{2}-\right.$ $\mathrm{N}$-decylPIILS). The initial TOF of $169 \mathrm{~mole}_{\mathrm{H} 2} \cdot \mathrm{mol}_{\mathrm{cat}}{ }^{-1} \cdot \mathrm{min}^{-1} \mathrm{ob}-$ tained with PtNP@PPh ${ }_{2}$-PEGPIILS is among the highest for a PtNP-based catalyst compared to literature reports. A study of the reaction kinetics revealed that the hydrolysis is first order in catalyst and sodium borohydride with apparent activation energies of $23.9 \mathrm{~kJ} \mathrm{~mol}^{-1}$ and of $35.6 \mathrm{~kJ} \mathrm{~mol}^{-1}$ for PtNP@PPh PEGPIILS and PtNP@PPh $-N$-decyIPIILS, respectively. While the principle role of the PIIL is to stabilize the metal nanoparticles, the improvement in catalyst performance arising from the incorporation of the N-PEGylated imidazolium compared with its $\mathrm{N}$-decyl counterpart may be associated with a change in the balance of hydrophilicity/hydrophobicity which could (i) increase the dispersibility of the catalyst and facilitate access to more exposed active sites, (ii) modify catalyst-support inter- actions to render substrate activation more favorable or (iii) facilitate interaction of the borohydride, formation of the surface bound hydrogen-bonded $\left[\mathrm{BH}_{3}-\mathrm{H}-\mathrm{H}-\mathrm{OH}\right]^{-}$ensemble and activation of the water towards oxidative addition. Primary $\mathrm{KIE}\left(k_{\mathrm{H}} / k_{\mathrm{D}}\right)$ of 1.8 and 2.1 obtained in $\mathrm{D}_{2} \mathrm{O}$ indicates rate determining $\mathrm{O}-\mathrm{H}$ bond cleavage of water facilitated by hydrogen bonding with a hydridic $\mathrm{B}-\mathrm{H}$ bond of surface bound borohydride. The catalyst retained $70 \%$ of its activity over five reuses and poisoning studies indicated that the loss in activity was most likely due to deactivation by the metaborate hydrolysis product as the activity could be restored by washing. A tandem reaction that used the hydrogen generated from the hydrogenation of $\mathrm{NaBH}_{4}$ in $\mathrm{D}_{2} \mathrm{O}$ for the hydrogenation of 1,1diphenylethene generated a mixture of all eight possible isotopologues, which is consistent with facile H/D scrambling on the surface of the nanoparticle prior to reductive elimination to generate $\mathrm{H}_{2}, \mathrm{H}-\mathrm{D}$ and $\mathrm{D}_{2}$ as well as facile and competitive $\beta$ hydride elimination-reinsertion during the hydrogenation. We are currently exploring the efficacy of $\mathbf{3} \mathbf{a}-\mathbf{b}$ as catalysts for the dehydrogenation of ammonia borane and dimethylamine borane and will extend this study to a host of other hydrogen rich substrates as well as integrate the most efficient systems into a continuous flow process. Moreover, the concept of PIILstabilized NPs will enable synergistic bimetallic and non-noble metal catalyst to be developed that are more cost effective, stable, durable, and highly active for the release of hydrogen from hydrogen rich materials as well as the hydrogen evolution reaction. The modular composition of the PIIL supports will also lend itself to modifying properties such as ionic microenvironment and charge density, number and type of heteroatom donors, surface potential, hydrophilicity, and porosity and thereby substrate accessibility and catalyst surface interactions and ultimately catalyst efficacy.

\section{Experimental Section}

Synthesis of $\left[\mathrm{PtCl}_{4}\right] @ \mathrm{PPh}_{2}$-PEGPIILS (2 a). A round-bottomed flask was charged with PPh $_{2}$-PEGPIIL co-polymer $(3.04 \mathrm{~g}, 2.0 \mathrm{mmol})$ and water $(45 \mathrm{fmmol})$ in water $(3-4 \mathrm{~mL})$. The resulting red/orange mixture was stirred for $12 \mathrm{~h}$ after which the precipitate was collected by filtration through a sintered frit and washed with distilled water $(3 \times 15 \mathrm{~mL})$, ethanol $(3 \times 20 \mathrm{~mL})$ and diethyl ether $(3 \times$ $20 \mathrm{~mL}$ ) to afford $2 \mathrm{a}$ as a red/brown powder in $80 \%$ yield $(1.62 \mathrm{mmol}, 2.80 \mathrm{~g})$ after exhaustive drying under high vacuum. ICP-OES data: $8.5 \mathrm{wt} \%$ platinum corresponding to a platinum loading of $0.43 \mathrm{mmol} \mathrm{g}^{-1}$.

Synthesis of $\left[\mathrm{PtCl}_{4}\right] @ \mathrm{PPh}_{2}-\mathrm{N}$-decyIPIILS (2 b). A round-bottomed flask was charged with $\mathrm{PPh}_{2}-\mathrm{N}$-decylPIIL co-polymer $(5.00 \mathrm{~g}$, $4.48 \mathrm{mmol})$ and water $(65 \mathrm{~mL})$ and stirred vigorously while adding a solution of $\mathrm{K}_{2}\left[\mathrm{PtCl}_{4}\right](1.86 \mathrm{~g}, 4.48 \mathrm{mmol})$ in water $(3-4 \mathrm{~mL})$. The resulting red/orange mixture was stirred for $12 \mathrm{~h}$, after which the precipitate was collected by filtration and washed with distilled water $(3 \times 15 \mathrm{~mL})$, ethanol $(3 \times 20 \mathrm{~mL})$ and diethyl ether $(3 \times 20 \mathrm{~mL})$ to afford $2 \mathrm{~b}$ as a red/brown powder in $92 \%$ yield $(4.10 \mathrm{mmol}$, $5.50 \mathrm{~g})$ after exhaustive drying under high vacuum. ICP-OES data: $13 \mathrm{wt} \%$ platinum corresponding to a platinum loading of $0.66 \mathrm{mmol} \mathrm{g}^{-1}$. 
Synthesis of PtNP@PPh charged with $\left[\mathrm{PtCl}_{4}\right] @ \mathrm{PPh}_{2}$-PEGPIILS $(2.50 \mathrm{~g}, 1.45 \mathrm{mmol})$ and ethanol $(50 \mathrm{~mL})$ and the resulting suspension treated dropwise with a solution of $\mathrm{NaBH}_{4}(0.43 \mathrm{~g}, 11.6 \mathrm{mmol})$ in water $(3 \mathrm{~mL})$.. The solution instantly turned from orange to black. After stirring at room temperature for $12 \mathrm{hr}$ the solvent was removed under vacuum and the resulting solid was triturated with acetone $(3 \times 20 \mathrm{~mL})$, transferred to a sintered glass frit and washed with water $(2 \times 20 \mathrm{~mL})$, ethanol $(3 \times 20 \mathrm{~mL})$ and diethyl ether $(3 \times 20 \mathrm{~mL})$ and dried under high vacuum to afford 3 a as a dark brown solid in $78 \%$ yield $\%$. ICP-OES data: $7.1 \mathrm{wt} \%$ platinum and a platinum loading of $0.36 \mathrm{mmol} \mathrm{g}^{-1}$.

Synthesis of PtNP@PPh ${ }_{2}-\mathrm{N}$-decylPIILS (3 b). A round bottom flask was charged with $\left[\mathrm{PtCl}_{4}\right] @ \mathrm{PPh}_{2}-\mathrm{N}$-decylPIILS $(3.58 \mathrm{~g}, 2.67 \mathrm{mmol})$ and ethanol $(60 \mathrm{~mL})$ and the resulting suspension treated dropwise with a solution of $\mathrm{NaBH}_{4}(0.80 \mathrm{~g}, 21.38 \mathrm{mmol})$. The solution instantly turned from orange to black. After stirring at room temperature for $12 \mathrm{hr}$ the solvent was removed under vacuum and the resulting solid was triturated with acetone $(3 \times 20 \mathrm{~mL})$, transferred to a sintered glass frit, and washed with water $(2 \times 20 \mathrm{~mL})$, ethanol $(3 \times$ $20 \mathrm{~mL})$ and diethyl ether $(3 \times 20 \mathrm{~mL})$ and dried under high vacuum to afford $\mathbf{3 b}$ as a dark brown solid in $81 \%$ yield. ICP-OES data: $15 \mathrm{wt} \%$ platinum and a platinum loading of $0.77 \mathrm{mmol} \mathrm{g}^{-1}$.

Platinum Nanoparticle-Catalyzed Hydrolysis of Sodium Borohydride. Catalytic hydrolysis reactions were conducted in water at the appropriate temperature in a thermostated $50 \mathrm{~mL}$ round bottom flask. The flask was charged with a stirrer bar, an appropriate quantity of catalyst $(0.32 \mathrm{~mol} \%, 0.0050 \mathrm{~g} 3 \mathrm{a} ; 0.32 \mathrm{~mol} \% 0.0026 \mathrm{~g}$ $3 \mathrm{~b})$ and $\mathrm{NaBH}_{4}(0.021 \mathrm{~g}, 0.57 \mathrm{mmol})$ and fitted with a gas outlet which was connected to the top of an inverted water-filled burette. The reaction was initiated by adding water $(2 \mathrm{~mL})$, immediately sealing the system by replacing the gas outlet, opening the tap of the water filled burette and recording the time zero volume. Gas evolution began immediately, and the progress of the reaction was monitored by measuring the amount of gas generated by recording the volume of water displaced from the burette at regular time intervals $(15 \mathrm{sec})$. The optimum turnover frequency for each catalyst was determined by conducting a series of experiments with catalyst loadings ranging from $0.08-0.32 \mathrm{~mol} \%$ at $30^{\circ} \mathrm{C}$ and measuring the hydrogen generated, as described above. Kinetic studies were also conducted as described above using $0.32 \mathrm{~mol} \% 3 \mathrm{a}$ and $0.69 \mathrm{~mol} \%$ $3 \mathrm{~b}$ across a range of temperatures $\left(21^{\circ} \mathrm{C}, 25^{\circ} \mathrm{C}, 30^{\circ} \mathrm{C}, 35^{\circ} \mathrm{C}\right.$ and $40^{\circ} \mathrm{C}$ ) to determine the apparent activation energy $\left(\mathrm{E}_{\mathrm{a}}\right)$.

Determination of the Reaction Order for the PtNP-Catalyzed Hydrolysis of Sodium Borohydride. The rate law was investigated by conducting the catalytic hydrolysis reactions at $35^{\circ} \mathrm{C}$ with a constant concentration of $\mathrm{NaBH}_{4}(0.284 \mathrm{M}, 0.021 \mathrm{~g}$ in water $(2 \mathrm{~mL}))$ across a range of catalyst concentrations from $0.08 \mathrm{~mol} \%$ to $0.64 \mathrm{~mol} \%$ for $\mathbf{3 a}$ and $0.34 \mathrm{~mol} \%$ to $1.73 \mathrm{~mol} \%$ for $\mathbf{3 b}$. The influence of sodium borohydride concentration on the rate of hydrolysis was determined by conducting reactions at $25^{\circ} \mathrm{C}$ in water $(200 \mathrm{~mL})$ with catalysts $3 \mathbf{a}$ and $\mathbf{3} \mathbf{b}(26 \mu$ mole) and varying the quantity of sodium borohydride from $26.5 \mu$ mole to $158 \mu$ mole $\left(\left[\mathrm{NaBH}_{4}\right]_{0}=0.13,0.26,0.39,0.52,0.65,0.78 \mathrm{mM}\right)$, which corresponds to catalyst: $\mathrm{NaBH}_{4}$ ratios of between $1: 1$ and 1:6.

Catalyst Recycle Studies for the Hydrolysis of Sodium Borohydride. Recycle studies were conducted at $30^{\circ} \mathrm{C}$ as described above using $2 \mathrm{~mol} \% 3 \mathrm{a}$ to catalyze the hydrolysis of sodium borohydride $(0.021 \mathrm{~g}, 0.57 \mathrm{mmol}$ in water $(20 \mathrm{~mL}))$. After gas evolution had ceased the flask was recharged with a fresh portion of sodium borohydride $(0.021 \mathrm{~g}, 0.57 \mathrm{mmol})$ and the gas evolution monitored by recording the volume of water displaced from the burette at regular time intervals; this procedure was repeated five times.
Hot Filtration Tests. Hot filtration studies were conducted at $30^{\circ} \mathrm{C}$ following the protocol described above using $0.32 \mathrm{~mol} \% 3 \mathrm{a}$ to catalyze the hydrolysis of sodium borohydride $(0.021 \mathrm{~g}, 0.57 \mathrm{mmol}$ in water $(2 \mathrm{~mL}))$. The reaction was monitored by periodically measuring the amount of gas generated and when the reaction had reached about $50 \%$ conversion $(8 \mathrm{~min})$ the reaction mixture was quickly filtered through a $0.45 \mu \mathrm{m}$ syringe filter, and the gas generated was monitored for a further $30 \mathrm{~min}$. In an alternative procedure, a catalytic hydrolysis of $\mathrm{NaBH}_{4}(0.021 \mathrm{~g}, 0.57 \mathrm{mmol})$ using $0.32 \mathrm{~mol} \% 3 \mathrm{a}$ was allowed to reach completion after which the reaction mixture was filtered through a $0.22 \mu \mathrm{m}$ diameter syringe filter, a further portion of $\mathrm{NaBH}_{4}$ added $(0.021 \mathrm{~g}, 0.57 \mathrm{mmol})$ and the amount of gas evolved measured.

Catalyst Poisoning Study. A $50 \mathrm{~mL}$ round bottom flask was charged with a stirrer bar, catalyst 3 a $(2 \mathrm{~mol} \%, 0.0307 \mathrm{~g})$, water $(20 \mathrm{~mL})$ and sodium metaborate $(0.0765 \mathrm{~g}, 0.57 \mathrm{mmol})$ and the mixture stirred at $30^{\circ} \mathrm{C}$ for the allocated time $(t=0 \mathrm{~min}, 20 \mathrm{~min}$, $40 \mathrm{~min}, 60 \mathrm{~min}$ and $18 \mathrm{~h}$ ) to explore the effect of poisoning time on catalyst efficacy. The reaction was initiated by adding $\mathrm{NaBH}_{4}$ $(0.021 \mathrm{~g}, 0.57 \mathrm{mmol})$ and the progress of the reaction monitored by periodically measuring the amount of gas generated, according to the procedure described above.

Tandem Reactions for the Hydrogenation of 1,1-Diphenylethene. Tandem reactions were conducted in a double Schlenk flask system connected by tubing. One flask was charged with a stir bar, $\mathrm{NaBH}_{4}$ $(0.042 \mathrm{~g}, 1.11 \mathrm{mmol})$ or $\mathrm{NaBD}_{4}(0.046 \mathrm{~g}, 1.11 \mathrm{~mol}), 0.32 \mathrm{~mol} \% 3 \mathrm{a}$ $(0.005 \mathrm{~g})$. The hydrolysis was initiated by adding $\mathrm{D}_{2} \mathrm{O}(2 \mathrm{~mL})$ or $\mathrm{H}_{2} \mathrm{O}$ $(2 \mathrm{~mL})$ and the reaction flask was sealed with a stopper and isolated from the second flask. Meanwhile the second flask was charged with a stir bar, 1,1-diphenylethene $(0.180 \mathrm{~g}, 1.00 \mathrm{mmol}), 0.5 \mathrm{~mol} \%$ $\mathrm{Pd} / \mathrm{C}$ and $\mathrm{CH}_{3} \mathrm{OH}(2 \mathrm{~mL})$ or $\mathrm{d}_{4}$-methanol $(2 \mathrm{~mL})$. The hydrolysis was left for 30 mins after which time the second flask was evacuated briefly, and the connector opened. The hydrogenation mixture was stirred at $30^{\circ} \mathrm{C}$ for $18 \mathrm{~h}$, after which time the solvent was removed under vacuum and the resulting residue analyzed by ${ }^{13} \mathrm{C}\left\{{ }^{1} \mathrm{H}\right\} \mathrm{NMR}$ spectroscopy and GC-MS to determine the composition and the distribution of isotopologues.

\section{Acknowledgements}

R.P. thanks the EPSRC Centre for Doctoral Training in Renewable Energy Northeast Universities ('ReNU') EP/S023836/1 for a studentship and H.Y.A. gratefully acknowledges Taibah University, Saudi Arabia for a Scholarship. We also thank (Dr Tracey Davey) for the SEM images (Faculty of Medical Sciences, Newcastle University). Zabeada Aslam and the Leeds electron microscopy and spectroscopy centre (LEMAS) at the University of Leeds for TEM analysis and $\mathrm{Dr}$ Alex Kulak for EDX experiments. We thank to UK Engineering and Physical Sciences Research Council (EPSRC), on grant number NS/A000015/1 for support for XPS measurements at NEXUS facility at Newcastle University. This article is dedicated to the memory of Elwood, Jake and Ella, may they rest in peace.

\section{Conflict of Interest}

The authors declare no conflict of interest. 


\section{Data Availability Statement}

The data that support the findings of this study are available in the supplementary material of this article.

Keywords: catalytic hydrogen generation - deuterium labelling studies - metal nanoparticles - kinetics - recycle and catalyst poisoning $\cdot$ sodium borohydride

[1] F. Perera, Int. J. Environ. Res. Public Health 2018, 15, 16. doi.org/10.3390/ ijerph15010016.

[2] a) J. G. J. Olivier. J. A. H. W. Peters, Trends in Global $\mathrm{CO}_{2}$ and Total Green House Gas Emissions 2019 Report; b) $\mathrm{CO}_{2}$.earth Are we Stabilizing Yet? Prooxygen Web Site https://www.co2.earth/ (accessed 20 th September 2021); c) E. S. Sanz-Pérez, C. R. Murdock, S. A. Didas, C. W. Jones, Chem. Rev. 2016, 116, 11840-11876.

[3] a) R. E. Rodríguez-Lugo, M. Trincado, M. Vogt, F. Tewes, G. SantisoQuinones, H. Grützmacher, Nat. Chem. 2013, 5, 342-347; b) S. Akbayrak Y. Tonbul, S. Özkar, Dalton Trans. 2016, 45, 10969-10978; c) S. E. Hosseini, M. Abdul Wahid, Renewable Sustainable Energy Rev. 2016, 57, 850-866; d) M. S. Dresselhaus, I. L. Thomas, Nature 2001, 414, 332-347 e) M. Balla, M. Wietschel, Int. J. Hydrogen Energy 2009, 34, 615-627; f) X. Yu, Z. Tang, D. Sun, L. Ouyang, M. Zhu, Prog. Mat. Sci. 2017, 88, 1-48; g) L. Schlapbach, A. Zuttel, Nature 2001, 414, 353-358.

[4] a) F. A. de Bruijn, ChemSusChem 2008, 1, 782-783; b) T. K. Mandala, D. H. Gregory, Annu. Rep. Prog. Chem. Sect. A 2009, 105, 21-54; c) G. Cipriania V. Di Dio, F. Genduso, D. La Cascia, R. Liga, R. Miceli, G. R. Galluzzo, Int. J. Hydrogen Energy 2014, 39, 8482-8494; d) J. Yang, A. Sudik, C. Wolverton, D. J. Siege, Chem. Soc. Rev. 2010, 39, 656-675; e) T. B. Marder, Angew. Chem. Int. Ed. 2007, 46, 8116-8118; Angew. Chem. 2007, 119, 82628264.

[5] a) U. Eberle, M. Felderhoff, F. Schüth, Angew. Chem. Int. Ed. 2009, 48, 6608-6630; Angew. Chem. 2009, 121, 6732-6757; b) Q. Sun, N. Wang, Q. $\mathrm{Xu}, \mathrm{J}$. Yu, Adv. Mater. Interfaces 2020, 32, 2001818; c) C. Lang, Y. Jia, X. Yao, Energy Storage Mater. 2020, 26, 290-312; d) L. Lu, H. Zhang, S. Zhang, F. Li, Angew. Chem. Int. Ed. 2015, 54, 9328-9332; Angew. Chem. 2015, 127, 9460-9464; e) T. He, P. Pachfule, H. Wu, Q. Xu, P. Chen, Nat Rev. Mater. 2016, 1, 16059; f) B. Zhu, R. Zou, Q. Xu, Adv. Energy Mater. 2018, 8, 1801193; g) S. Akbayraka, S. Özkar, Int. J. Hydrogen Energy 2018, 43, 18592-18606; h) C. Yüksel, A. Senem, K. Gülbay, C. O. Colpan, Int. J. Hydrogen Energy 2020, 45, 3414-3434; i) A. Staubitz, A. P. M. Robertson, I. Manners, Chem. Rev. 2010, 110, 4079-4124; j) N. Zafirah Abd K Khafidz Z. Yaakob, K. L. Lim, S. N. Timmiati, Int. J. Hydrogen Energy 2016, 41 13131-13151; k) M. Yadav, Q. Xu, Energy Environ. Sci. 2012, 5, 96989725; I) U. B. Demirci, P. Miele, Energy Environ. Sci. 2009, 2, 627-637; m) X. Liu, X. Zhang, D.-S. Li, S. Zhang, Q. Zhang, J. Mater. Chem. A 2021, 9, 18164-18174.

[6] a) D. M. F. Santos, C. A. C. Sequeira, Renewable Sustainable Energy Rev. 2011, 15, 3980-4001; b) S. S. Muira, X. Yao, Int. J. Hydrogen Energy 2011, 36, 5983-5997; c) N. Patel, A. Miotello, Int. J. Hydrogen Energy 2015, 40, 1429-1464; d) B. H. Liu, Z. P. Li, J. Power Sources 2009, 187, 527-534 e) U. B. Demirci, Int. J. Hydrogen Energy 2017, 42, 21048-21062; f) P.-Y. Olu, A. Bonnefont, G. Braesch, V. Martin, E. R. Savinova, M. Chatenet, J. Power Sources 2018, 375, 300-309; g) H.-K. Lai, Y.-Z. Chou, M.-H. Lee, K.Y. A. Lin, Chem. Eng. J. 2018, 332, 717-726; h) P. Brack, S. E. Dann, K. G. U. Wijayantha, Energy Sci. Eng. 2015, 3, 174-188.

[7] a) P. Brack, S. E. Dann, K. G. U. Wijayantha, Energy Sci. Eng. 2015, 3, 174 188; b) K. Sordakis, C. Tang, L. K. Vogt, H. Junge, P. J. Dyson, M. Beller, G. Laurenczy, Chem. Rev. 2017, 118, 372-433; c) N. Onishi, G. Laurenczy, M. Beller, Y. Himeda, Coord. Chem. Rev. 2018, 373, 317-332; d) C.W. Hamilton, R. T. Baker, A. Staubitz, I. Manners, Chem. Soc. Rev. 2009, 38, 279-293; e) N. Onishi, M. Iguchi, X. Yang, R. Kanega, H. Kawanami, Q. Xu, Y. Himeda, Adv. Energy Mater. 2019, 9, 1801275

[8] a) Z. Li, Q. Xu, Acc. Chem. Res. 2017, 50, 1449-1458; b) W.-W. Zhan, Q.-L. Zhu, Q. Xu, ACS Catal. 2016, 6, 6892-6905; c) C. Wang, D. Astruc, Chem. Soc. Rev. 2021, 50, 3427-3484.

[9] a) X.-F. Yang, A. Wang, B. Qiao, J. Li, J. Liu, T. Zhang, Acc. Chem. Res. 2013, 46, 1740-1748; b) N. Wang, Q. Sun, J. Yu, Adv. Mater. 2019, 31, 1803966 ; c) G. A. Somorjai, A. M. Contreras, M. Montano, R. M. Rioux PNAS 2006, 103, 10577-10583; d) A. Cao, R. Lu, G. Veser, Phys. Chem. 2010, 12, 13499-13510; e) Y. Li, G. A. Somorjai, Nano Lett. 2010, 10,
2289-2295; f) R. Narayanan, M. A. El-Sayed J. Phys. Chem. B 2005, 109, 12633-12676; g) M. Moreno-Mañas, R. Pleixats, Acc. Chem. Res. 2003, 36, 638-643; h) C. J. Gommes, Nanoscale 2019, 11, 7386-7393; i) S. Cheong J. D. Watt, R. D. Tilley, Nanoscale 2010, 2, 2045-2053; j) H. Goesmann, C. Feldmann, Angew. Chem. Int. Ed. 2010, 49, 1362-1395; Angew. Chem. 2010, 122, 1402-1437.

[10] a) X. F. Yang, A. Wang, B. Qiao, J. Li, J. Liu, T. Zhang, Acc. Chem. Res. 2013, 46, 1740-1748; b) G. Schmid, Nanoparticles: From Theory to Applications, Wiley-VCH, Weinheim, 2004, 1-359.

[11] a) X. Qu, R. Jiang, Q. Li, F. Zeng, X. Zheng, Z. Xu, C. Chen, J. Peng, Green Chem. 2019, 21, 850-860; b) Y.-Y. Cai, X.-H. Li, Y.-N. Zhang, X. Wei, K.-X. Wang, J.-S. Chen, Angew. Chem. Int. Ed. 2013, 52, 11822-11825; Angew. Chem. 2013, 125, 12038-12041; c) F.-Z. Song, Q.-L. Zhu, X. Yang, W.-W. Zhan, P. Pachfule, N. Tsumori, O. Xu, Adv. Energy Mater. 2018, 8, 1701416; d) B. Zhu, R. Zou, Q. Xu, Adv. Energy Mater. 2018, 8, 1801193; e) P.-Z. Li, A. Aijaz, Q. Xu, Angew. Chem. Int. Ed. 2012, 51, 6753-6756; Angew. Chem. 2012, 124, 6857-6860; f) W. Chen, D. Li, C. Peng, G. Qian, X. Duan, D. Chen, X. Zhou, J. Catal. 2017, 356, 186-196; g) Y.-T. Li, X.-L. Zhang, Z.-K. Peng, P. Liu, X.-C. Zheng, ACS Sustainable Chem. Eng. 2020, 8, 8458-8468; h) X. Li, C. Zhang, M. Luo, Q. Yao, Z.-H. Lu Inorg. Chem. Front. 2020, 7, 1298-1306; i) R. Ding, Q. Chen, Q. Luo, L. Zhou, Y. Wang, Y. Zhang, G. Fan, Green Chem. 2020, 22, 835-842; j) M. Zahmakiran, T. Ayvali, S. Akbayrak, S. Caliskan, D. Celik, S. Ozkar, Catal. Today 2011, 170, 76-84; k) S. Akbayrak, Z. Özçifçi, A. J. Tabak, Colloid Sci. 2019, 546, 324332; I) L. Yin, T. Zhang, K. Dai, B. Zhang, X. Xiang, H. Shang, ACS Sustainable Chem. Eng. 2021, 9, 822-832.

[12] a) Q. Sun, N. Wang, Q. Bing, R. Si, J. Liu, R. Bai, P. Zhang, M. Jia, J. Yu, Chem. 2017, 3, 477-493; b) N. Wang, Q. Sun, R. Bai, X. Li, G. Guo, J. Yu, J. Am. Chem. Soc. 2016, 138, 7484-7487; c) Q. Sun, N. Wang, T. Zhang, R. Bai, A. Mayoral, P. Zhang, Q. Zhang, O. Terasaki, J. Yu, Angew. Chem. Int. Ed. 2019, 58, 18570-18576; Angew. Chem. 2019, 131, 18743-18749; d) M. Zahmakiran, S. Özkar, Langmuir 2009, 25, 2667-2678; e) Q. M. Sun N. Wang, T. J. Zhang, R. Bai, A. Mayoral, P. Zhang, Q. Zhang, O. Terasaki, J. Yu, Angew. Chem. Int. Ed. 2019, 58, 18570-18576; Angew. Chem. 2019 131, 18743-18749; f) Q. Sun, N. Wang, R. Bai, Y. Hui, T. Zhang, D. A. Do, P. Zhang, L. Song, S. Miao, J. Yu, Adv. Sci. 2019, 6, 1802350; g) N. Wang, Q. Sun, R. Bai, X. Li, G. Guo, J. Yu, J. Am. Chem. Soc. 2016, 138, 74847487.

[13] a) P. Verma, K. Yuan, Y. Kuwahara, K. Moria, H. Yamashita, Appl. Catal. B 2018，223，10-15; b) N. Patela, R. Fernandes, S. Gupta R Edla, D. C. Kothari, A. Miotello, Appl. Catal. B 2013, 140-141, 125-132; C) K. Mori, Y. Futamura, S. Masuda, H. Kobayashi, H. Yamashita, Nat. Commun. 2019, $10,4094$.

[14] a) H. Zhong, Y. Su, C. Cui, F. Zhou, X. Li, R. Wang, ACS Sustainable Chem. Eng. 2017, 5, 8061-8069; b) C. Cui, Y. Tang, M. A. Ziaee, D. Tian, R. Wang, ChemCatChem 2018, 10, 1431-1437.

[15] a) Q.-L. Zhu, J. Li, Q. Xu, J. Am. Chem. Soc. 2013, 135, 10210-10213; b) C. Wang, J. Tuninetti, Z. Wang, C. Zhang, R. Ciganda, L. Salmon, S. Moya, J. Ruiz, D. Astruc, J. Am. Chem. Soc. 2017, 139, 11610-11615; c) F. Fu, C. Wang, Q. Wang, A. M. Martinez-Villacorta, A. Escobar, H. Chong, X. Wang, S. Moya, L. Salmon, E. Fouquet, J. Ruiz D Astruc, J. Am. Chem. Soc. 2018, 140, 10034-10042; d) X. Gu, Z.-H. Lu, H.-L. Jiang, T. Akita, Q. Xu, J. Am. Chem. Soc. 2011, 133, 11822-11825; e) C. Luo, F. Fu, X. Yang, J. Wei, C. Wang, J. Zhu, D. Huang, D. Astruc, P. Zhao, ChemCatChem 2019, 11, 1643-1649; f) S. Zhang, L. Zhou, M. Chen, RSC Adv. 2018, 8, 1228212291; g) D. D. Tuan, K.-Y. A. Lin, Chem. Eng. J. 2018, 351, 48-55.

[16] a) N. Kang, R. Djeda, Q. Wang, F. Fu, J. Ruiz, J.-L. Pozzo, D. Astruc, ChemCatChem 2019, 11, 2341-2349; b) Q. Wang, F. Fu, A. Escobar, S Moya, J. Ruiz, D. Astruc, ChemCatChem 2018, 10, 2673-2680; c) Q. Wang, F. Fu, S. Yang, M. Martinez Moro, M. de los Angeles Ramirez, S. Moya, L. Salmon, J. Ruiz, D. Astruc, ACS Catal. 2019, 9, 1110-1119.

[17] a) J. D. Scholten, B. C. Leal, J. Dupont, ACS Catal. 2012, 2, 184-200; b) C. Janiak, Z. Naturforsch. 2013, 68b, 1059-1089; c) A. S. Pensando, A. A. H. Pádua, Angew. Chem. Int. Ed. 2011, 50, 8683-8687; Angew. Chem. 2011 123, 8842-8846; d) A. Kraynov, T. E. Müller (September 22 ${ }^{\text {nd }} 2011$ ). Concepts for the Stabilization of Metal Nanoparticles in lonic Liquids, Applications of Ionic Liquids in Science and Technology, Scott Handy, IntechOpen, DOI: 10.5772/22111. Available from: https://www.intechopen.com/books/applications-of-ionic-liquids-in-science-and-technology/concepts-for-the-stabilization-of-metal-nanoparticles-in-ionicliquids.

[18] For a relevant and insightful review see: a) F. Giacalone, M. Grutadauria, ChemCatChem 2016, 8, 664-684; See also b) W. Qian, J. Texter, F. Yam, Chem. Soc. Rev. 2017, 46, 1124-1159; c) H. Li, P. S. Bhadury, B. Song, S Yang, RSC Adv. 2012, 2, 12525-12551; d) K. Manojkumar, A. Sivaramak- 
rishna, K. Vijayakrishna, J. Nanopart. Res. 2016, 18, 103; e) S. Montolio, C. Vicent, V. Aseyev, I. Alfonso, M. I. Burguete, H. Tenhu, E. García-Verdugo, S. V. Luis, ACS Catal. 2016, 6, 7230-7237; f) A. Bordet, W. Leitner, Acc Chem. Res. 2021, 54, 2144-2157.

[19] a) M. Guo, H. Li, X. Ren, Q. Yang, C. Li, ACS Catal. 2018, 8, 6476-6485; b) X. Ren, M. Guo, H. Li, L. Yu, Q. Yang, Angew. Chem. Int. Ed. 2019, 58, 14483-14488; Angew. Chem. 2019, 131, 14625-14630; c) S. Jayakumar, A. Modak, M. Guo, H. Li, X. Hu, Q. Yang, Chem. Eur. J. 2017, 23, 77917797; d) M. Guo, C. Li, Q. Yang, Catal. Sci. Technol. 2017, 7, 2221-2227; e) F. Para da Silva, J. L. Fiorio, L. M. Rossi, ACS Omega 2017, 2, 60146022; f) J. Mondal, S. K. Kundu, W. K. H. Ng, R. Singuru, P. Borah, H. Hirao, H. Y. Zhao, A. Bhaumik, Chem. Eur. J. 2015, 21, 19016-19027; g) J. Tan, J. Cui, G. Ding, T. Deng, Y. Zhu, Y.-W. Li, Catal. Sci. Technol. 2016, 6, 1469-1475; h) G. Chen, C. Xu, X. Huang, J. Ye, L. Gu, G. Li, Z. Tang, B. Wu, H. Yang, Z. Zho, Z. Zhou, G. Fu, N. Zheng, Nat. Mater. 2016, 15, 564$569 ;$ i) S. G. Kwon, G. Krylova, A. Sumer, M. M. Schwartz, E. E. Bunel, C. L. Marshall, S. Chattopadhyay, B. Lee, J. Jellinek, E. V. Shevchenko, Nano Lett. 2012, 12, 5382-5388; j) W. Long, N. A. Brunelli, S. A. Didas, E. W. Ping, C. W. Jones, ACS Catal. 2013, 3, 1700-1708; k) H. Liu, Q. Mei, S. Li, Y. Yang, Y. Wang, H. Liu, L. Zheng, P. An, J. Zhang, B. Han, Chem. Commun. 2018, 54, 908-911; I) J. B. Ernst, C. Schwermann, G. Yokota, M. Tada, S. Muratsugu, N. L. Doltsinis, F. Glorius, J. Am. Chem. Soc. 2017 139, 9144-9147; m) J. Ernst, S. Muratsugu, F. Wang, M. Tada, F. Glorious, J. Am. Chem. Soc. 2016, 138, 10718-10721; n) G. Salas C C Santini, K. Philippot, V. Colliere, B. Chaudret, B. Fenet, P. F. Fazzini, Dalton Trans. 2011, 40, 4660-4668.

[20] a) S. Doherty, J. G. Knight, T. Backhouse, E. Abood, H. Alshaikh, I. A. J. Fairlamb, R. A. Bourne, T. W. Chamberlain, R. Stones, Green Chem. 2017 19, 1635-1641; b) S. Doherty, J. G. Knight, T. Backhouse, A. Bradford, F. Saunders, R. A. Bourne, T.W. Chamberlain, R. Stones, A. Clayton, K Lovelock, Catal. Sci. Technol. 2018, 8, 1454-1467; c) S. Doherty, J. G. Knight, T. Backhouse, E. Abood, H. Alshaikh, A. Clemmet, J. R. Ellison, R. A. Bourne, T. W. Chamberlain, R. Stones, I. A. J. Fairlamb, K. Lovelock, Adv. Synth. Catal. 2018, 360, 3716-3731; d) S. Doherty, J. G. Knight, T. Backhouse, W. Simpson, W. Paget, E. Abood, R. A. Bourne, T. W. Chamberlain, R. Stones, K. R. J. Lovelock, J. M. Seymour, M. A. Isaacs, H. Daley, C. Hardacre, N. H. Rees, ACS Catal. 2019, 9, 4777-4791; e) S. Doherty, J. G. Knight, T. Backhouse, T. S. T. Tran, F. Stahl, H. Y. Alharbi, T. W. Chamberlain, R. A. Bourne, R. Stones, J.P. White, Z. Aslam, C. Hardacre, H. Daly, J. Hart, R. H. Temperton, J. N. O'Shea, N. H. Rees, Catal. Sci. Technol. 2021, submitted for publication.

[21] K. N. Han, C. A. Li, M. .-P. N. Bui, X. .-H. Pham, B. S. Kim, Y. H. Choa, G. H. Seong, Sens. Actuators B 2012, 174, 406-413.

[22] a) I. Simagina, P. A. Storozhenko, O. V. Netskina, O. V. Komova, G. V. Odegova, T. Y. Samoilenko, A. G. Gentsler, Kinet. Catal. 2007, 48, 168175; b) G. Guella, B. Patton, A. Miotello, J. Phys. Chem. C 2007, 111, 18744-18750; c) G. Guella, C. Zanchetta, B. Patton, A. Miotello, J. Phys. Chem. B 2006, 110, 17024-17033.

[23] a) C. Salameh, A. Bruma, S. Malo, U. B. Demirci, P. Miele, S. Bernard, RSC Adv. 2015, 5, 58943-58951; b) A. Lale, A. Wasan, R. Kumar, P. Miele, U. B.
Demirci, S. Bernard, Int. J. Hydrogen Energy 2016, 41, 15477-15488; c) A. Uzundurukan, Y. Devrim, Int. J. Hydrogen Energy 2019, 44, 17586-17594; d) S. Saha, V. Basak, A. Dasgupta, S. Ganguly, D. Banerjee, K. Kargupta Int. J. Hydrogen Energy 2014, 39, 11566-11577; e) C. Wu, J. Zhang, J. Guo, L. Sun, J. Ming, H. Dong, Y. Zhao, J. Tian, X. Yang, ACS Sustainable Chem. Eng. 2018, 6, 7451-7457; f) P. Dai, X. Zhao, D. Xu, C. Wang, X. Tao, X. Liu, J. Gao, Int. J. Hydrogen Energy 2019, 44, 28463-28470; g) $\mathrm{O}$. Majoulet, C. Salameh, M. E. Schuster, U. B. Demirci, Y. Sugahara, S. Bernard, P. Miele, Chem. Mater. 2013, 25, 3957-3970; h) X. Wang, Y. Zhao, X. Peng, J. Wang, C. Jing, J. Tian, Mater. Sci. Eng. B 2015, 200, 99106; i) A. Lale, M. D. Mallmann, S. Tade, A. Bruma, S. Özkar, R. Kumar, M. Handa, R. A. F. Machado, Y. Iwamoto, U. B. Demirci, S. Bernard, Appl. Catal.. B 2020, 272, 118975; j) A. Zabielaitè, A. Balčiūnaitè, I. Stalnionienè, S. Lichušina, D. Šimkūnaitè, J. Vaičiūnienè, B. ŠimkūnaitèStanynienè, A. Selskis, L. Tamašauskaitè-Tamašiūnaitè, E. Norkus, Int. J. Hydrogen Energy 2018, 43, 23310-23318; k) S. M. Sachau, M. Zaheer, A. Lale, M. Freidrich, C. E. Denner, U. B. Demirci, S. Bernard, G. Motz, R. Kempe, Chem. Eur. J. 2016, 22, 15508-15512; I) L. Semiz, N. Abdullayeva, M. Sankir, J. Alloys Compd. 2018, 744, 110-115.

[24] Q. Yao, K. Yang, X. Hong, X. Chen, Z.-H. Lu, Catal. Sci. Technol. 2018, 8, 870-877.

[25] X. Qu, R. Jiang, Q. Li, F. Zeng, X. Zheng, Z. Xu, C. Chen, J. Peng, Green Chem. 2019, 21, 850-560.

[26] C. Huff, E. Biehler, Q. Quach, J. M. Long, T. M. Abdel-Fattah, Colloids Surf. A Physicochem. Eng. Asp. 2021, 610, 125734.

[27] Y. Wei, Y. Wang, L. Wei, X. Zhao, X. Zhou, H. Liu, Int. J. Hydrogen Energy 2018, 43, 592-600.

[28] Y. Karatas, A. Aygun, M. Gulcan, F. Sen, J. Taiwan Inst. Chem. Eng. 2019, $99,60-65$.

[29] N. Zhang, G. Liu, Y. Sun, Y. Wang, J. Yan, X. Liu, Catal. Lett. 2021, 151, 2272-2278.

[30] R. R. Retnamma, A. Q. Novais, C. M. Rangel, Int. J. Hydrogen Energy 2011, $36,9772-9790$

[31] A. Schneemann, J. L. White, S. Y. Kang, S. Jeong, L. F. Wan, E. S. Cho, T. W. Heo, D. Prendergast, J. J. Urban, B. C. Wood, M. D. Allendorf, V. Stavila, Chem. Rev. 2018, 118, 10775-10839.

[32] W. Chen, J. Shen, Y. Huang, X. Liu, D. Astruc, ACS Sustainable Chem. Eng. 2020, 8, 7513-7522.

[33] a) M. Rakap, S. Ozkar, Int. J. Hydrogen Energy 2010, 35, 3341-3346; b) M. Rakap, Appl. Catal. B 2015, 163, 129-134; c) Q.-L. Zhu, J. Li, Q. Xu, J. Am. Chem. Soc. 2013, 135, 10210-10213.

Manuscript received: November 17, 2021

Revised manuscript received: December 17, 2021

Accepted manuscript online: December 20, 2021

Version of record online: 


\section{RESEARCH ARTICLE}

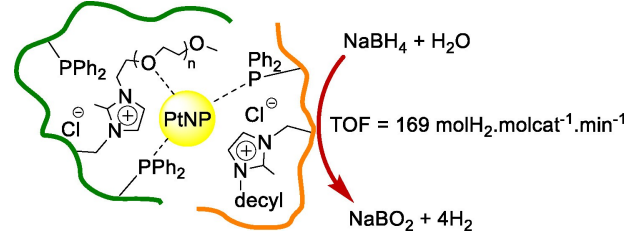

Immobilized ionic liquid: Platinum nanoparticles stabilized by imidazolium-based phosphine-decorated Polymer Immobilized Ionic Liquids catalyze the hydrolytic evolution of hydrogen from sodium borohydride with a TOF of $169 \mathrm{moleH}_{2} \cdot$ molcat $^{-1} \cdot \mathrm{min}^{-1}$.
Deuterium labelling studies for a tandem hydrogenation of 1,1-diphenylethene gave a mixture of all eight possible isotopologues consistent with facile reversible $\beta$-hydride elimination-reinsertion as well as rapid H/D exchange on $\mathrm{Pd} / \mathrm{C}$.
Dr. S. Doherty*, Dr. J. G. Knight*, H. Y. Alharbi, R. Paterson, Dr. C. Wills, Dr. C. Dixon, Dr. L. Šiller, Dr. T. W. Chamberlain*, A. Griffiths, Dr. S. M. Collins, Dr. K. Wu, Dr. M. D. Simmons, Prof. R. A. Bourne, Dr. K. R. J. Lovelock, J. Seymour $1-15$

Efficient Hydrolytic Hydrogen Evolution from Sodium Borohydride Catalyzed by Polymer Immobilized Ionic Liquid-Stabilized Platinum Nanoparticles 